\title{
Review
}

\section{Passive Immunization in Alpha-Synuclein Preclinical Animal Models}

\author{
Jonas Folke ${ }^{1,2,3, *}$, Nelson Ferreira ${ }^{4}\left(\mathbb{D}\right.$, Tomasz Brudek ${ }^{2,3}\left(\mathbb{D}\right.$, Per Borghammer ${ }^{5,6}$ and Nathalie Van Den Berge $5,6, * \mathbb{D}$ \\ 1 Department of Geriatric Medicine, University Hospital Essen, 45147 Essen, Germany \\ 2 Research Laboratory for Stereology and Neuroscience, Department of Neurology, Bispebjerg-Frederiksberg \\ Hospital, University Hospital of Copenhagen, 2400 Copenhagen, Denmark; tomasz.brudek@regionh.dk \\ 3 Copenhagen Center for Translational Research, Bispebjerg-Frederiksberg Hospital, University Hospital of \\ Copenhagen, 2400 Copenhagen, Denmark \\ 4 DANDRITE-Danish Research Institute of Translational Neuroscience, Department of Biomedicine, \\ Aarhus University, 8000 Aarhus, Denmark; nelson@biomed.au.dk \\ 5 Department of Clinical Medicine, Aarhus University, 8000 Aarhus, Denmark; borghammer@clin.au.dk \\ 6 Department of Nuclear Medicine and PET, Aarhus University Hospital, 8200 Aarhus, Denmark \\ * Correspondence: Jonas.folke@regionh.dk (J.F.); nathalie.vandenberge@clin.au.dk (N.V.D.B.)
}

Citation: Folke, J.; Ferreira, N.; Brudek, T.; Borghammer, P.; Van Den Berge, N. Passive Immunization in Alpha-Synuclein Preclinical Animal Models. Biomolecules 2022, 12, 168. https:// doi.org/10.3390/biom12020168

Academic Editor: Vladimir N. Uversky

Received: 2 December 2021

Accepted: 15 January 2022

Published: 20 January 2022

Publisher's Note: MDPI stays neutral with regard to jurisdictional claims in published maps and institutional affiliations.

Copyright: (C) 2022 by the authors. Licensee MDPI, Basel, Switzerland. This article is an open access article distributed under the terms and conditions of the Creative Commons Attribution (CC BY) license (https:// creativecommons.org/licenses/by/ $4.0 /)$.

\begin{abstract}
Alpha-synucleinopathies include Parkinson's disease, dementia with Lewy bodies, pure autonomic failure and multiple system atrophy. These are all progressive neurodegenerative diseases that are characterized by pathological misfolding and accumulation of the protein alpha-synuclein ( $\alpha$ syn) in neurons, axons or glial cells in the brain, but also in other organs. The abnormal accumulation and propagation of pathogenic $\alpha$ syn across the autonomic connectome is associated with progressive loss of neurons in the brain and peripheral organs, resulting in motor and non-motor symptoms. To date, no cure is available for synucleinopathies, and therapy is limited to symptomatic treatment of motor and non-motor symptoms upon diagnosis. Recent advances using passive immunization that target different $\alpha$ syn structures show great potential to block disease progression in rodent studies of synucleinopathies. However, passive immunotherapy in clinical trials has been proven safe but less effective than in preclinical conditions. Here we review current achievements of passive immunotherapy in animal models of synucleinopathies. Furthermore, we propose new research strategies to increase translational outcome in patient studies, (1) by using antibodies against immature conformations of pathogenic $\alpha$ syn (monomers, post-translationally modified monomers, oligomers and protofibrils) and (2) by focusing treatment on body-first synucleinopathies where damage in the brain is still limited and effective immunization could potentially stop disease progression by blocking the spread of pathogenic $\alpha$ syn from peripheral organs to the brain.
\end{abstract}

Keywords: alpha-synuclein; passive immunization; disease stratification

\section{Introduction}

Twenty-five years ago, it was found that aggregated alpha-synuclein ( $\alpha$ syn) is the major protein component of Lewy pathology [1]. Subsequent studies discovered that point mutations within or duplications/triplications of the $\alpha$ syn gene (SNCA) are linked to familial PD [2-4]. These findings indicate a central role of $\alpha$ syn in Lewy body diseases (LBD). Since then, Parkinson's disease (PD), dementia with Lewy bodies (DLB), pure autonomic failure (PAF) and multiple system atrophy (MSA) are classified as synucleinopathies, also called $\alpha$-synucleinopathies, as they all are characterized by pathological accumulation of the protein $\alpha$ syn. PD, DLB and PAF predominantly present with intraneuronal and neuritic deposits of misfolded $\alpha$ syn, i.e., Lewy bodies and Lewy neurites. Furthermore, the accumulation of pathogenic $\alpha$ syn is associated with progressive disrupted cellular function, neuronal death and subsequent dysfunction in the central and peripheral nervous system [5]. MSA is a distinct case of $\alpha$-synucleinopathies, as it is characterized by predominant glial cytoplasmic inclusions (GCIs) [6], later also called Papp-Lantos bodies [7]. 
Patients are classified as PD, DLB, PAF or MSA based on their clinical symptoms and later, post-mortem by the spatiotemporal distribution of pathogenic $\alpha$ syn [8]. The spatiotemporal distribution is likely dependent on a combination of different factors, disease onset site and neuroanatomical connections as well as cellular vulnerability and the presence of concomitant tau and/or $\mathrm{A} \beta$ pathology. The clinical representation of $\mathrm{PD}$, DLB, PAF and MSA patients is highly heterogeneous esp. in early disease stages, and displays a large clinical overlap, as each $\alpha$-synucleinopathy may include a wide range of motor, cognitive, gastrointestinal and/or other autonomic disturbances, complicating early and accurate diagnosis. For example, DLB merely differentiates from PD diagnosis by the occurrence of cognitive dysfunction prior to motor dysfunction by only one year [9], which is very short, considering that non-motor symptoms occur up to 20 years prior to motor symptoms in PD [10]. PD, DLB and MSA show both central and peripheral nervous system involvement of $\alpha$ syn pathology [11,12]. In PAF, $\alpha$ syn pathology is confined within the autonomic nervous system (ANS) without motor dysfunction [13]. These patients also have an increased risk to pheno-convert into other $\alpha$-synucleinopathies later in life, possibly indicating a pathophysiological disease continuum [12]. Furthermore, MSA patients with autonomic-only presentation in the early disease stage can be misdiagnosed as PAF. Moreover, MSA patients presenting with parkinsonism may be misdiagnosed as PD [14]. These $\alpha$-synucleinopathies progress at different velocities with different intensities, but may evolve to similar advanced disease stages over time where the entire body is affected $[15,16]$.

Currently, there is no cure for any of these $\alpha$-synucleinopathies; hence, there is a great interest in targeting pathogenic $\alpha$ syn as a strategy to halt disease progression. To reduce levels of harmful misfolded $\alpha$ syn, a clearing process of the protein has to be established. This can be achieved with immunotherapies using vaccination strategies with antibodies directed against harmful $\alpha$ syn [17]. The aim of a particular immunotherapy is to reduce the amount of misfolded $\alpha$ syn in the body, and thereby block the spread of pathogenic $\alpha$ syn, consequently reducing progressive neurodegeneration and, therefore, symptoms [18]. Passive immunization with naturally occurring autoantibodies (nAbs) that are part of the innate immune system is considered more safe than active immunization or vaccination where an antigen is injected to induce the production of antibodies [19]. Preclinical studies using nAbs have shown reduced trans-synaptic spread of pathogenic $\alpha$ syn, as well as improved motor and cognitive deficits in PD mouse models. In contrast, preliminary data from on-going clinical phase I and phase II trials using passive immunotherapies targeting different forms of $\alpha$ syn are unable to demonstrate efficacy in reducing disease progression [20]. Whether nAbs provide protection against developing PD, increasing evidence suggests that anti- $\alpha$ syn nAbs may have a protecting effect in inhibiting $\alpha$ syn seeding and can recognize Lewy body pathology [21]. nAbs have been extensively evaluated in PD as reviewed by Scott et al. [22]; however, most studies have been restricted to assessing total IgG nAbs levels. A few studies have evaluated IgG nAb subclasses, IgM nAbs and the binding properties of these nAbs, showing a switched immunological response in PD and MSA patients and further a reduced binding towards $\alpha$ syn [23-25]. A more thorough evaluation is needed to fully map the immunological responses in PD and other synucleinopathies.

Discrepancy between animal and patient studies might be explained by a combination of poor $\alpha$ syn targeting and poor patient selection. The strain hypothesis in $\alpha-$ synucleinopathies postulates that each disease entity is characterized by a distinct conformation of pathogenic $\alpha$ syn; therefore, each $\alpha$-synucleinopathy could be caused by a unique $\alpha$ syn structure or strain. This implies that different $\alpha$-synucleinopathies require different $n$ Abs targeting a specific $\alpha$ syn strain. Unfortunately, clinical trials lack accurate patient stratification and individual disease heterogeneity is often not considered during patient recruitment, as trials assume a common pathogenetic mechanism of disease across patients. The highly heterogeneous profile of the prodromal disease phase of $\alpha$-synucleinopathies make early and accurate stratification very challenging. Consequently, patients are often misdiagnosed at early disease stages and may not benefit from a certain immunotherapy. 
Further, patients in advanced disease stages with established major neurodegeneration might benefit less compared to prodromal patients. It remains to be elucidated whether the formation of mature dense $\alpha$ syn or Lewy pathology aggravates or protects against neurodegeneration [26]. It is hypothesized that endogenous $\alpha$ syn goes through four stages to ultimately form mature Lewy pathology: misfolding of endogenous $\alpha$ syn, oligomerization, formation of fibrils and, finally, development of dense inclusions. The immature oligomeric and fibrillary $\alpha$ syn appear to be most toxic compared to mature Lewy pathology [27], indicating such conformers could be particularly attractive as therapeutic targets instead of mature Lewy pathology. Lack of these considerations might have contributed to disappointing results. Future trials should focus on enrolment of prodromal patients after detailed stratification into different disease subtypes by using disease- and strain-specific biomarkers. Additionally, target biology should be optimized towards immature strainspecific pathology. For this purpose, it is crucial to gain insight in the earliest physiological to pathological events underlying $\alpha$ syn misfolding and abnormal aggregation using animal models of $\alpha$-synucleinopathies. Here, we discuss recent developments of passive immunization in animal models of $\alpha$-synucleinopathies, their shortcomings and highlight the potential utility of novel experimental models and considerations for future clinical trials to increase translation ability of results.

\section{2. $\alpha$ syn and Its Role in the Pathogenesis of Synucleinopathies}

asyn was first discovered in 1988 in the Common torpedo (an electric ray species). It is an abundantly expressed protein in the brain, located in the presynaptic nerve terminals [28]. In humans, $\alpha$ syn is a 140 amino-acid protein encoded by the SNCA gene and is part of the synuclein protein family including beta $(\beta)$ - and gamma $(\gamma)$-synuclein [29]. $\alpha$ syn has three domains: a N-terminal domain (residue 1-60); a central hydrophobic domain (residue 61-95), also called the non-amyloid- $\beta$ component (NAC), and a negatively charged C-terminal domain (residue 96-140) [30]. $\alpha$ syn exists in equilibrium between soluble cytosolic and membrane-associated forms. The N-terminal domain adopts an $\alpha$-helical structure facilitating lipid membrane interaction [30]. This membrane association of $\alpha$ syn most probably contributes to synaptic trafficking, accelerating vesicle reuptake by promoting membrane curvature [31,32]. However, several gaps of knowledge in the precise role of $\alpha$ syn need to be elucidated. The native form of $\alpha$ syn is a monomer, but due to its soluble state as an intrinsically disordered protein, $\alpha$ syn is prone to self-assemble or misfold into a variety of insoluble oligomeric species. Studies have shown that the conditions are pivotal for the oligomeric species, some more toxic than others [33], thus demonstrating the difference in LB or GCI formation.

$\alpha$ syn is likely to exist both as unstructured monomers and helical oligomers [34,35]. However, the existence of free helical structures has been debated since recapitulation of helical oligomers could only be provided with addition of lipids [36], N-terminal acetylation [37] and N-terminal extension in lipid-free environment [35], which impact a more uniform aggregation of $\alpha$ syn $[38,39]$. The central region, the NAC domain, corresponding to aa 71-82 is essential for misfolding and aggregation [40]. What precise mechanisms initiate aggregation and determine the end-stage polymorphic structure within multimers and fibrils, still needs to be resolved. Since the discovery of mutations in a familial phenotype of PD, several other genetic alterations have been directly linked to PD. All familial PD related mutations in the SNCA gene translated into missense mutations in the protein (A30P, E46K, H50Q, G51D, and A53T), are all located in the N-terminal and clustered around the $\alpha$ syn protein loop [41], and further found to alter oligomerization [42]. It is now believed that the aggregation of $\alpha$ syn is the centralizing micro pathological change in $\alpha$-synucleinopathies. How $\alpha$ syn drives PD pathology remains elusive, and it remains to be elucidated whether the formation of mature Lewy bodies is neuroprotective or a facilitator of neurodegeneration [26]. However, recent findings implicate that the presence of oligomeric $\alpha$ syn is the primary cause of neurotoxicity and plays a critical role in PD pathophysiology and propagation of pathology [43]. Importantly, the development of PD 
pathology and associated neurodegeneration is most likely a combination of several risk factors that, besides the formation of pathogenic $\alpha$ syn, also include neuroinflammation, failing proteostasis mechanisms, mitochondrial dysfunction, endoplasmic reticulum stress, and synaptic and cell impairments.

Based on Braak's theory [44], later updated by others [45], the pattern of $\alpha$ syn spread in PD is divided into six successive stages; starting from early Lewy neurite (LN) lesions in non-dopaminergic structures of the lower brainstem, e.g., the dorsal motor nucleus of the vagus nerve in the medulla, ascending to the brain or from the olfactory nuclei to the cortex prior to symptomatic manifestations in stage 1, to more widespread LBs in the basal ganglia structures, manifesting early motoric symptoms with pale precursors of LBs in the substantia nigra pars compacta (SNpc) in stage 2. From Braak stage 3 to 4 , asyn lesions (LNs and LBs) propagate with further neuronal depletions in the amygdala and nucleus basalis of Meynert to severely damaged structures in the SNpc. In the late stage of PD (stage 5), the LB's from the mesocortex transmit to the temporal and prefrontal neocortices, while in the end stage (stage 6), lesions are affecting the primary sensory and motor areas, constituting the entire neocortex [44-46]. Later, the LB staging has been revised, with $\alpha$ syn pathology starting in either the olfactory bulb or the enteric cell plexi [47]. Even more recently, studies have shown that $\alpha$ syn pathology in preclinical PD may occur simultaneously in multiple regions of both the peripheral and central nervous system [48]. Interestingly, $\alpha$ syn pathology has been observed in incidental LB disease, where individuals have no clinical Parkinsonian manifestations [48]. DLB patients share similar pathological changes to PD patients; however, since many PD patients develop dementia (PDD) as the disease progresses, the separation between PDD and DLB patients is currently being debated, also neuropathologically. Similar to PD patients, the majority of DLB patients show degeneration of dopaminergic neurons in the SNpc [49]. The main difference lies in pathological changes affecting the neocortex and limbic system in DLB compared to PD patients. Microscopically, DLB is presented with widespread accumulation of LNs and LBs similar to the Braak staging system in PD. The consensus, however, divides DLB patients neuropathologically based on LB-related pathology, whether the distribution is centralized in the brainstem, limbic or neocortical regions [50]. Besides $\alpha$ syn pathology, coexistent Alzheimer's disease (AD) pathology, sufficient for a secondary diagnosis of $\mathrm{AD}$, is observed in about $50 \%$ of DLB patients. The pattern of coexistent AD pathology is usually not associated with the $\alpha$ syn propagation pattern [51].

In MSA, the main lesion pathology is found as GCIs [6], later confirmed to be made up primarily of $\alpha$ syn [52]. Compared to incidental LB pathology, GCIs are rarely, if ever, observed in aging individuals without clinical symptoms. Thus, the definite diagnosis of MSA relies primarily on the presence of widespread GCIs [53]. Besides GCIs, MSA patients are also presented with glial nuclear inclusions, neuronal cytoplasmic inclusions and neuronal nuclear inclusions [54]. Since MSA patients are characterized by low-density spread of LBs, MSA is not considered a LB disease [55]. Studies showed that $\alpha$ syn pathology in GCIs differ in post-translational permutations resulting in cell type specific insoluble conformational structures [56]. MSA patients are divided into two subgroups depending on their clinical manifestations and macro/microscopic pathology: MSA-P with predominantly parkinsonian symptoms and MSA-C with cerebellar symptomatology [53]. In fact, the $\alpha$ syn burden of pathology projections seems to be highly associated with the subtype of MSA [57]. In addition to MSA-P and MSA-C there are several other subtypes of MSA, including minimal change MSA, non-motor MSA and incidental MSA (i.e., GCI pathology in the absence of clinical features) [58]. In the case of minimal change MSA, there is widespread GCI pathology but without clear corresponding neuro- or oligodendrogliopathy and a general absence of other clinical signs. Minimal change MSA can be interpreted as a coincidental, but distinct subtype, with diffuse LBD [59].

PAF is a very rare sporadic neurodegenerative disorder characterized by failure of the autonomic system. LBs in the peripheral autonomic nervous system underlie the majority of pathology in PAF. asyn accumulates in the form of LBs within the sympathetic ganglia 
and in axons of autonomic neurons e.g., heart, bladder, skin and colon [60]. Occasional LBs in the SNpc and locus coeruleus have been reported [60], indicating pheno-conversion to PD. The precise and low-density widespread $\alpha$ syn accumulation in PAF remains unclear.

\section{Prion-like Behavior and Gut-to-Brain Propagation}

$\alpha$ syn is unequivocally linked to neurological disease. However, the pathophysiological mechanisms underlying $\alpha$-synucleinopathies are still unknown. A seminal study in two PD patients showed that surviving transplanted fetal nigral neurons developed Lewy bodies over time, indicating pathogenic $\alpha$ syn from a patient's brain is able to spread to healthy grafted neurons $[61,62]$. The ability of pathogenic $\alpha$ syn to convert normal endogenous asyn protein into pathogenic misfolded asyn (also called 'seeding'), and subsequently propagate to a neighboring neuron is called conformational templating. The phenomenon of conformational templating was first discovered in prion diseases where a pathogenic seed recruits cellular prion protein $(\mathrm{PrPc})$ and converts it into a toxic isoform called a prion (PrPSc) $[63,64]$. Similar to prions, oligomeric $\alpha$ syn species are also able to template or seed intracellular aggregation of $\alpha$ syn in vitro [33]. In $\alpha$-synucleinopathies, it has been shown that misfolded $\alpha$ syn can convert into toxic isoforms such as oligomers that accumulate into fibrils. These fibrils are capable of crossing the neuronal membrane and once transferred into a new cell, can convert normal $\alpha$ syn into misfolded $\alpha$ syn that further evolves into oligomeric and fibrillar $\alpha$ syn, hereby initiating an auto-replicating process [26].

Besides in the brain, $\alpha$ syn pathology is also observed in several peripheral organs of PD and MSA patients [9,10] including the gut [65-67], heart [68] and skin [69-71]. Some of these studies observed pathology in the gut $[65,72]$ or skin $[12,69,73]$ at early prodromal disease stages, demonstrating its potential as early disease biomarker. Additionally, nonmotor autonomic symptoms, including constipation, orthostatic hypotension, pain, urinary and sweating problems are common in early PD and MSA, and occur up to 20 years prior to motor symptoms [10,74-76]. These findings support that pathogenic $\alpha$ syn can transmit from cell to cell within the central nervous system (CNS), as well as from the peripheral nervous system (PNS) to the CNS in a prion-like fashion. Several preclinical studies have shown mechanistically that pathogenic $\alpha$ syn is able to template and spread transsynaptically in a prion-like fashion (reviewed in $[77,78]$ ). Interestingly, it has been shown that $\alpha$ syn propagation within sensory afferents is concomitant with impaired nociceptive response, reflected by mechanical allodynia, reduced nerve conduction velocities (sensory and motor) and degeneration of small- and medium-sized myelinated fibers, suggesting that $\alpha$ syn trans-neuronal transmission and conformational templating might underlie the multifaceted etiology and symptomatology of pain in PD [79].

Despite extensive investigation, mechanisms inducing $\alpha$ syn misfolding are still unclear. It has been suggested that pathogenic $\alpha$ syn can initiate in the gut due to exposure to environmental toxins that enter the gut lumen, affecting gut permeability and oxidative stress via endocrine cells in the gut epithelium, ultimately leading to the formation of misfolded $\alpha$ syn in the myenteric plexus, and spread to the brain via peripheral nerves [80]. Importantly, oral gavage with the pesticide rotenone in old mice induced formation of misfolded $\alpha$ syn in parasympathetic and sympathetic nuclei of the CNS [81]. The gut-tobrain transmission of pathogenic $\alpha$ syn is difficult to study in living patients. However, recent experimental animal models of PD have been able to recapitulate this aspect of PD pathogenesis. Researchers have shown that injections of pathogenic $\alpha$ syn in the gut of rodents induces pathogenic $\alpha$ syn in brainstem structures from 1 month post injection, and subsequently induces a caudo-rostral spread of pathology [82,83], paralleled by loss of dopaminergic neurons as well as motor and or non-motor symptoms resembling idiopathic PD $[83,84]$. Interestingly, pathogenic $\alpha$ syn did not ascend into the brain when animals underwent truncal vagotomy [84]. Also in humans, it has been shown that truncal vagotomy reduces the risk of PD by 40-50\% after 10-20 years of follow-up, indicating that cutting the vagal nerve inhibits the spread of $\alpha$ syn pathology to the brain $[85,86]$. Additionally, bidirectional gut-to-brain and brain-to-gut propagation of pathology along the vagus nerve 
was observed post injection of pathogenic $\alpha$ syn in the gut of rodents, as well as propagation to the heart and skin along sympathetic nerves, like observed in human PD [82,83]. Therefore, these models probably provide the most complete recapitulation of human PD to date. Taken together, these findings suggest that strategies aimed at prevention of cell-to-cell and gut-to-brain transmission of $\alpha$ syn could slow down or halt transmission of toxic $\alpha$ syn confomers and progression of symptoms in synucleinopathies, and that these models would be most suitable for developing such treatment strategies.

\section{Subtypes of $\alpha$-Synucleinopathies}

The hypothesized gut-to-brain spread of $\alpha$ syn in PD (and other synucleinopathies) is still heavily debated, since several autopsy studies could not confirm the proposed caudorostral spread and showed that $\alpha$ syn pathology in the CNS is quite often present without the occurrence of $\alpha$ syn in the ENS, vagus nerve or dorsal motor nucleus of the vagus nerve $[87,88]$. Overall, post-mortem studies have reported two principal types of pathology patterns: a brainstem-predominant type with more pathology in the brainstem than more rostral structures and a limbic/amygdala-predominant type, with more midbrain pathology compared to more caudal structures $[16,89]$. This observation has led to the body-first vs. brain-first hypothesis, a hypothesized stratification of PD subtypes based on the onset site of pathology, first described in 2019 by Borghammer and Van Den Berge [90]. The body-first type is associated with a brainstem-predominant pathology pattern in the brain, and is characterized by REM sleep behavior disorder (RBD) in the pre-motor phase and autonomic dysfunction (orthostatic hypotension and pathological 123I-metaiodobenzylguanidine (MIBG) heart scintigraphy) prior to motor dysfunction [91], as well as gut and skin tissue biopsies positive for aggregated $\alpha$ syn [72,73]. Isolated RBD is a common finding among patients with synucleinopathies, usually coincides with other autonomic disturbances and is considered to be an early stage of (body-first) $\alpha$-synucleinopathy [92-94]. In contrast, the brain-first type is hypothesized to be associated with a limbic/amygdala-predominant pathology pattern in the brain, and is characterized by an RBD-negative prodromal phase and nigrostriatal dopamine deficit prior to autonomic dysfunction. Both disease subtypes converge to a homogeneous advanced disease stage over time where the entire brain and several peripheral organs are affected. The existence of these subtypes is supported by in vivo imaging studies of isolated RBD and de novo PD patient groups. Isolated RBD and de novo PD with RBD (i.e., body-first subtype) were characterized by cardiac and enteric denervation, measured with MIBG SPECT and donepezil PET, respectively, and a relatively normal brain scan. In contrast, PD patients without RBD (i.e., brain-first subtype) were characterized by nigrostriatal neurodegeneration measured with FDOPA PET and a less pathological heart and gut scan, indicating damage to the brain precedes autonomic damage in the brain-first subtype, and vice versa in the body-first subtype [91].

In extension to the body-first vs. brain-first hypothesis, it has been recently postulated that the clinical representation and distribution of $\alpha$ syn pathology in those two PD subtypes could be explained by varying disease onset site, body or brain, as well as the neural connectome [15]. According to this $\alpha$ syn Origin site and Connectome (SOC) model, in the brain-first subtype, $\alpha$ syn pathology arises in a single hemisphere of the brain, leading to asymmetric limbic-predominant pathology in the brain, after which it spreads to the body. According to the SOC model, in the body-first subtype, $\alpha$ syn pathology arises in any peripheral organ (usually the gut), after which it spreads bilaterally, via overlapping vagal innervation, to the brainstem, leading to a bilateral and more symmetric brainstempredominant pathology distribution in the brain [15]. Recent imaging studies [91] and neuropathological evidence [16] are in support of this SOC model. Nigrostriatal degeneration measured with FDOPA PET and DaT SPECT was significantly more symmetric in patients with iRBD and de novo PD with RBD versus PD patients without RBD. These data support that body-first PD is characterized by more symmetric distribution, most likely due to more symmetric propagation of pathogenic $\alpha$ syn within the brain, compared to 
brain-first PD [95]. The SOC model actually applies to all LBD, including DLB and PAF patients [15].

In addition, validity of the SOC model is observed in animal models of PD, with symmetric involvement of the lower brainstem initially, upon peripheral initiation of pathology (gastrointestinal, intravenous, intraperitoneal or oral). This is followed by progressive symmetric involvement of the substantia nigra, limbic, and cortical regions in a predictable fashion. In contrast, unilateral initiation of pathology in the brain causes progressive predominant ipsilateral CNS involvement that is 3 to 10 fold higher than in the contralateral hemisphere. The pattern of CNS pathology (and symptoms) upon intracerebral initiation is highly dependent on the location of the first pathology. Therefore, brain-first PD is more heterogeneous compared to body-first PD [96].

\section{Therapeutic Strategies Targeting $\alpha$ syn Pathology}

Several mechanisms either neutralizing or facilitating clearance of toxic pathological asyn species have been suggested and attempted, and although there have been considerable advances, none to this date have been deemed successful in clinical trials [97]. Several approaches for modulating these toxic species have been proposed such as to reduce $\alpha$ syn expression by lowering RNA levels [98,99], by increasing proteasomal or autophagy activity [100], by inhibiting oligomerization/fibrillation with small molecules [101] or by interference and clearance using immunotherapy. Immunotherapy is an appealing way, harvesting the immune system's own resources in clearing potential toxic protein structures. There are two paths in pursuing immunotherapy: active immunization or passive immunization. Active immunization involves activation of the immune system to specific parts or conformational structures of $\alpha$ syn. Most prominent in clinical trials with PD and MSA patients are active immunization using small 8-amino acid peptides, that mimic small regions of human $\alpha$ syn called affitopes (PD01A and PD03A), developed by the company AFFiRiS [102]. Another clinical active vaccination trial is under way from United biomedical Inc., also using a C-terminal region-specific epitope [103]. Although less expensive than passive immunization strategies, one main obstacle is that it requires the patient's immune system to actively recognize and activate the immunological cascade which triggers the formation of new antigen-specific $B$ and T cells, and in consequence the antigen-specific antibodies. An important issue when exploring active vaccination strategies is the already existing autoimmunity. Evidence implicates that autoimmunity is a wide-ranging process of PD progression and recent studies suggest that $\mathrm{T}$ cells in certain PD haplotypes are auto-reactive towards $\alpha$ syn $[104,105]$. Whether they recognize native or newly formed neoepitopes remains to be elucidated, and whether this autoimmunity serves as protective or pathogenic need to be investigated further. One important notion is that a potential active vaccination needs to overcome immune tolerance to self-antigens whilst avoiding autoimmunity.

As one of the main approaches of immunoregulatory therapies in $\alpha$-synucleinopathies, passive immunization is based on continuous and chronic administration of $\alpha$ syn- and/or conformation-specific antibodies, hereby recognizing toxic epitopes, facilitating clearance by innate immune cells, halting the spreading of pathogenic $\alpha$ syn aggregates and potentially modifying disease progression. Although passive immunization cannot penetrate cell membranes, administration of $\alpha$ syn antibodies could halt cell-to-cell transmission and clean up excess amounts extracellularly (see Figure 1). Moreover, passive immunization with continuous administration offers advantage in controlling several variable parameters during the treatment e.g., systemic antibody levels, bypassing uncontrolled T-cell stimulations and controlling adverse side-effects. Furthermore, specific antibodies can be engineered to function specifically and be raised against specific conformational epitopes. Even though passive immunization comes with several disadvantages such as high costs, time-consumption and side-effects such as hypersensitivity, it does not outweigh the advantages for patients. Although it has no overt disease symptoms, it could slow down the progression and retain the patient on hold in the prodromal phase with only few 
none-invalidating symptoms. Moreover, in more severe cases such as seen in MSA and DLB patients, it can severely improve life expectancy and quality of life.

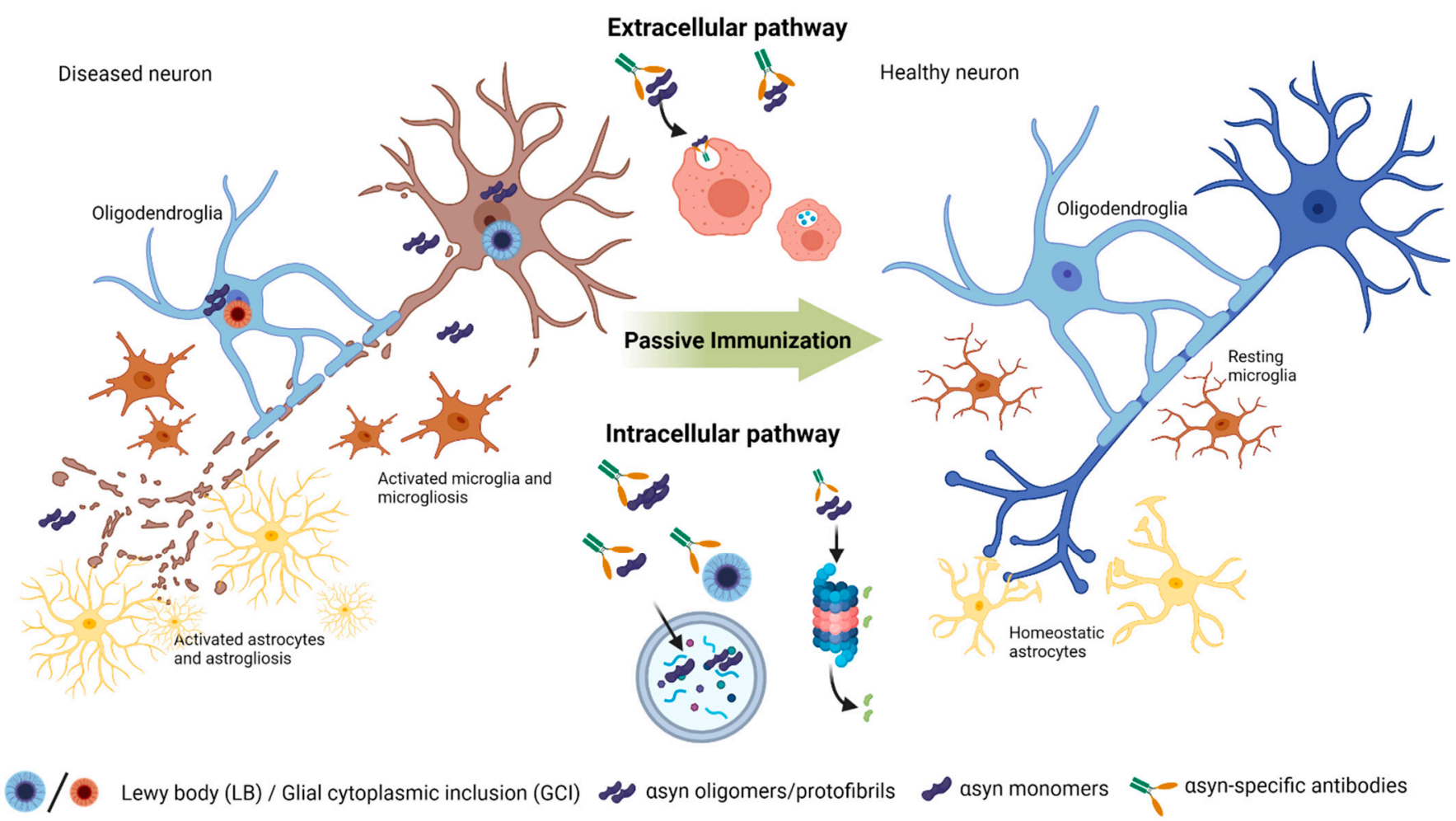

Figure 1. Clearing process of pathogenic alpha-synuclein ( $\alpha$ syn) using naturally occurring $\alpha$ syn conformation-specific antibodies in passive immunization. In synucleinopathies, pathogenic $\alpha$ syn species (proto/fibrillary or oligomeric) accumulate and potentially seed monomeric $\alpha$ syn facilitating transmission, and additionally triggering microglial and astrocytic activation. In PD and DLB, $\alpha$ syn aggregates in neurons form LBs. Whereas in MSA, $\alpha$ syn accumulates in oligodendroglial cells, forming GCIs. Administration of $\alpha$ syn-specific antibodies could facilitate clearance of pathogenic $\alpha$ syn in the extracellular space by phagocytosis reducing transmission of pathogenic species or enable intracellular antibody-aided autophagy and proteosomic degradation, both pathways leading to reduced pathogenic $\alpha$ syn and rescue of neuronal degradation. Created using Biorender.com (accessed on 30 November 2021).

\section{Passive Immunization Strategies in Animal Models and Clinical Trials}

Numerous passive immunization strategies have and are currently being tested in preclinical animal models (Table 1). 
Table 1. Passive immunization studies in Parkinsonian animal models.

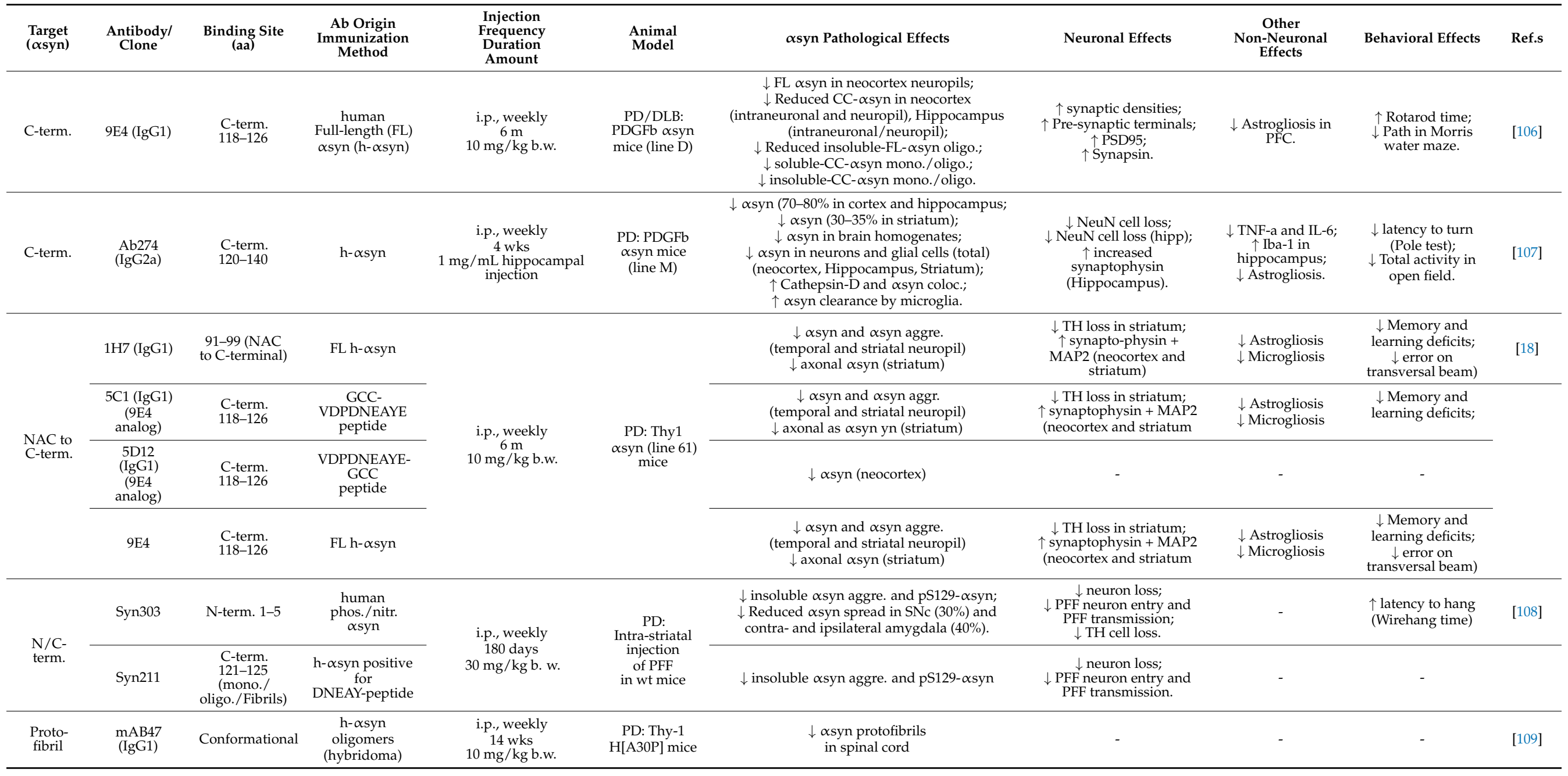


Table 1. Cont.

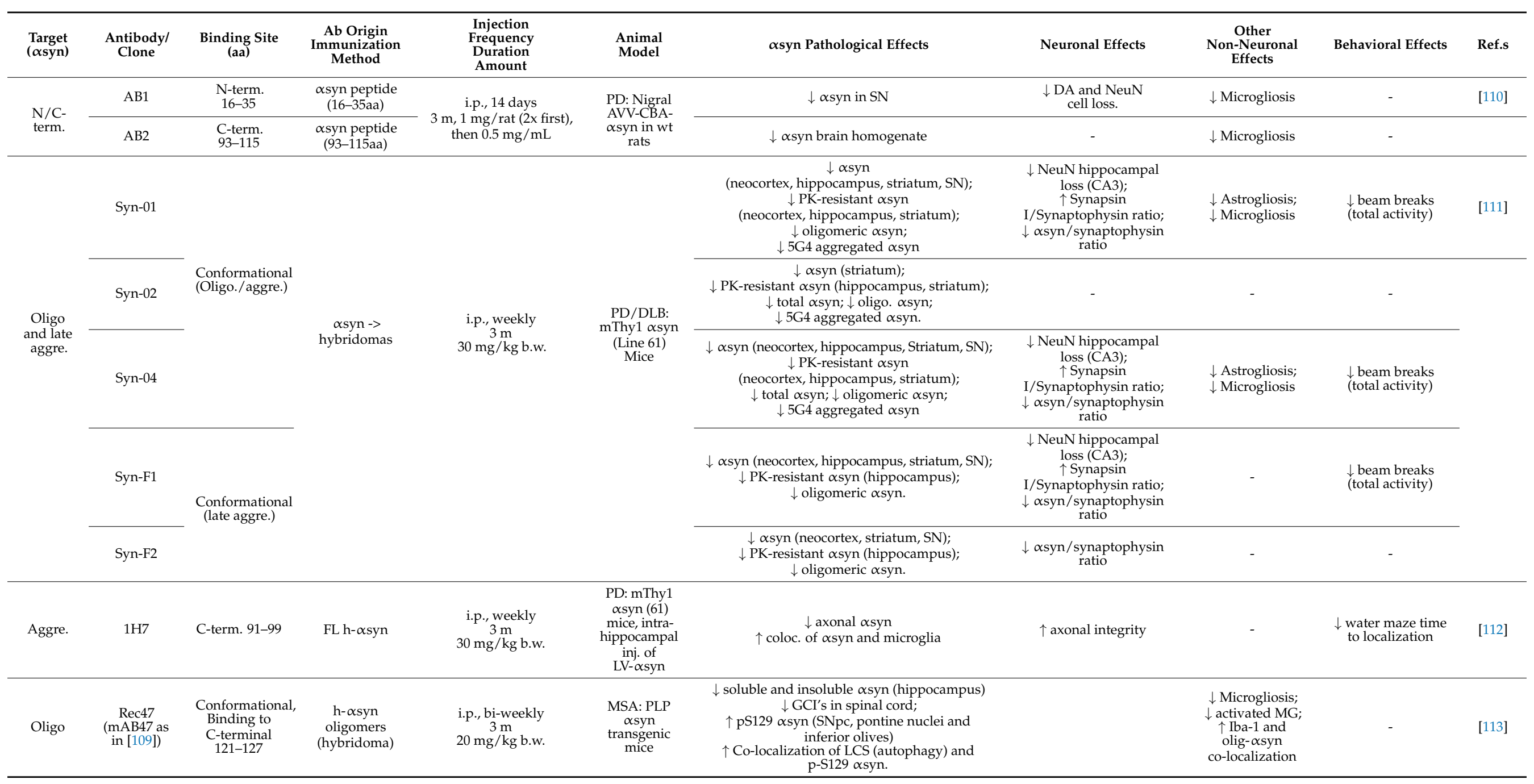


Table 1. Cont.

\begin{tabular}{|c|c|c|c|c|c|c|c|c|c|c|}
\hline $\begin{array}{l}\text { Target } \\
\text { ( } \alpha \text { syn) }\end{array}$ & $\begin{array}{l}\text { Antibody/ } \\
\text { Clone }\end{array}$ & $\underset{\text { (aa) }}{\text { Binding Site }}$ & $\begin{array}{c}\text { Ab Origin } \\
\text { Immunization } \\
\text { Method }\end{array}$ & $\begin{array}{l}\text { Injection } \\
\text { Frequency } \\
\text { Duration } \\
\text { Amount }\end{array}$ & Animal Model & $\alpha$ syn Pathological Effects & Neuronal Effects & $\begin{array}{c}\text { Other } \\
\text { Non-Neurronal } \\
\text { Effects }\end{array}$ & Behavioral Effects & Ref.s \\
\hline Aggre. & $\underset{(\operatorname{IgG1})}{\operatorname{MEDI1341}}$ & C-term. & $\begin{array}{l}\text { Human phage } \\
\text { library cloned } \\
\text { into IgG1 }\end{array}$ & $\begin{array}{c}\text { i.p., weekly } \\
13 \text { wks } \\
20 \mathrm{mg} / \mathrm{kg} \text { b.w. }\end{array}$ & $\begin{array}{l}\text { PD: mThy1 } \\
\text { csyn (Line 61) } \\
\text { mice- intra- } \\
\text { hippocampal } \\
\text { injection of } \\
\text { LV- } \alpha \text { syn }\end{array}$ & $\begin{array}{c}\downarrow \text { contralateral and ipsilateral } \alpha \text { syn } \\
\text { (hippocampus); } \\
\downarrow \text { contralateral axonal } \alpha \text { syn } \downarrow \text { asyn } \\
\text { (neocortex) } \\
\downarrow \text { interstitial fluid } \alpha \text { syn levels } \\
\downarrow \downarrow \text { CSF fluid } \alpha \text { syn levels } \\
\downarrow \text { asyn positive neurons (neocortex and } \\
\text { hippocampus) }\end{array}$ & - & - & - & [114] \\
\hline \multirow[b]{2}{*}{$\begin{array}{l}\text { Mono. } \\
\text { and } \\
\text { Oligo. }\end{array}$} & \multirow[b]{2}{*}{$\begin{array}{c}\mathrm{nAb} \\
\text { isolated } \\
\text { from IViG }\end{array}$} & & \multirow[b]{2}{*}{$\begin{array}{l}\text { nAbs isolated } \\
\text { from IViG using } \\
\text { asyn column } \\
\text { chromatography }\end{array}$} & $\begin{array}{l}\text { s.c., weekly } \\
4 \text { wks } \\
\text { Low dosage: } 0.8 \\
\text { mg/kg b.w. }\end{array}$ & \multirow[b]{2}{*}{$\begin{array}{l}\text { PD: A53T tg } \\
\text { mice }\end{array}$} & $\begin{array}{c}\downarrow \text { pS129- } \alpha \text { syn (brainstem) } \\
\downarrow \text { soluble } \alpha \text { syn (brainstem) }\end{array}$ & & $\begin{array}{c}\downarrow \text { Astroglio- } \\
\text { sis(Striatum); } \\
\uparrow \text { Microglia and } \\
\alpha \text { syn coloc. }\end{array}$ & $\begin{array}{l}\downarrow \text { Pole test (time to } \\
\text { descend/time to } \\
\text { turn). }\end{array}$ & [115] \\
\hline & & & & $\begin{array}{c}\text { s.c., weekly } \\
4 \text { wks } \\
\text { High dosage: } \\
2.4 \mathrm{mg} / \mathrm{kg} \text { b.w. }\end{array}$ & & 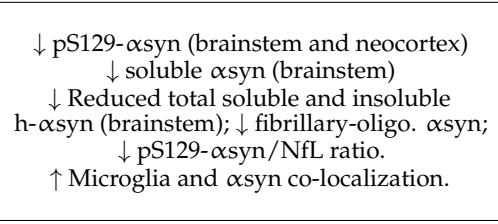 & $\begin{array}{l}\uparrow \text { PSD95 (brainstem), } \\
\uparrow \text { synaptophysin } \\
\text { (brainstem); } \\
\downarrow \text { TH cell loss } \\
\text { (striatum, brainstem) }\end{array}$ & $\begin{array}{c}\downarrow \text { astroglio- } \\
\text { sis(striatum) } \\
\downarrow \text { microglio- } \\
\text { sis(striatum); } \\
\downarrow \text { MCP- } \\
\text { 1(brainstem). }\end{array}$ & $\begin{array}{l}\downarrow \text { Pole test (time to } \\
\text { descend/time to } \\
\text { turn); } \\
\uparrow \text { Body suspension } \\
\text { test (hanging); } \\
\uparrow \text { Y maze } \\
\text { (duration in new } \\
\text { arm/new entries). }\end{array}$ & \\
\hline Aggre. & $\begin{array}{c}\text { Syn9048 } \\
\text { (IgG1) }\end{array}$ & C-term. & hybridoma & $\begin{array}{c}\text { i.p., weekly } \\
6 \mathrm{~m} \\
30 \mathrm{mg} / \mathrm{kg}\end{array}$ & $\begin{array}{l}\text { PD: } w t+\alpha \text { syn } \\
\text { PFF }(5 \mu \mathrm{g}) \\
\text { unilateral inj. in } \\
\text { dorsal striatum }\end{array}$ & $\begin{array}{c}\downarrow \alpha \text { syn ipsilateral SN; } \\
\downarrow \text { Contralateral amygdala. }\end{array}$ & $\downarrow$ DA cell loss; $\uparrow$ DOPAC & - & - & [116] \\
\hline \multirow{3}{*}{ Aggre. } & \multirow{3}{*}{$\begin{array}{l}\text { BIIB054/ } \\
\text { cinpanemab }\end{array}$} & \multirow{3}{*}{$\begin{array}{l}\text { N-term: } 1-10 \\
\text { (800-fold } \\
\text { greater } \\
\text { affinity to } \\
\text { aggregated } \\
\propto \text { \&syn) }\end{array}$} & \multirow{3}{*}{$\begin{array}{l}\text { Healthy human } \\
\text { memory B cells } \\
\text {-> clones }\end{array}$} & \multirow{3}{*}{$\begin{array}{c}\text { i.p., weekly } \\
60,90 \text { or } 100 \text { days } \\
30 \mathrm{mg} / \mathrm{kg} \text { b.w. }\end{array}$} & $\begin{array}{c}\text { PD: } w t \\
\text { C57BL/6JRccHsd } \\
\text { mice } \\
+\alpha \text { syn PFF } \\
\text { intrastrial inj. }\end{array}$ & $\downarrow$ truncated $\alpha$ syn $6 \mathrm{kd}(100 \mathrm{~d})$ & - & - & $\begin{array}{l}\uparrow \text { Hangwire } \\
\text { (latency to fall, } \\
60 \mathrm{~d} \text { ) }\end{array}$ & [117] \\
\hline & & & & & 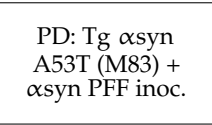 & - & - & - & $\begin{array}{c}\downarrow \text { paralysis }(7 \mathrm{~d}) \\
\downarrow \text { severe paralysis } \\
\quad(5 \mathrm{~d}) ; \\
\downarrow \text { weight loss }(9 \mathrm{~d}) .\end{array}$ & \\
\hline & & & & & $\begin{array}{c}\text { PD: BAC } \alpha \text { syn } \\
\text { A53T }+\alpha \text { syn } \\
\text { PFF intrastrial } \\
\text { inj. }\end{array}$ & - & $\begin{array}{l}\uparrow \text { contralateral DAT } \\
\text { levels (striatum, 90d) }\end{array}$ & - & - & \\
\hline $\begin{array}{l}\text { NAC- } \\
\text { region }\end{array}$ & NAC32 & $53-87$ & $\begin{array}{l}\text { Yeast surface } \\
\text { display library } \\
\text { of an entire } \\
\text { naîve repertoire } \\
\text { of human scFV } \\
\text { antibodies }\end{array}$ & $\begin{array}{c}\text { Stereotaxis } \\
\text { (AAV-NAC32) } \\
\text { post } 12 \text { wks after } \alpha \text { syn } \\
\text { inj. } \\
\text { Beh. } 4,8 \text { and } 12 \mathrm{wks} \\
\text { after NAC32 inj. }\end{array}$ & $\begin{array}{l}\text { PD: DAT-Cre } \\
\text { rats + AAV-DIO- } \\
\alpha \text { syn in SNpc. }\end{array}$ & $\downarrow \alpha \operatorname{syn}(25 \%)$ (SNpc dorsal). & $\begin{array}{l}\downarrow \text { TH cell loss (SNpc } \\
\text { dorsal) }\end{array}$ & - & $\begin{array}{l}\downarrow \text { Horizontal } \\
\quad \text { activity; } \\
\downarrow \text { Total distance } \\
\quad \text { travelled; } \\
\downarrow \text { Movement } \\
\quad \text { number; } \\
\downarrow \text { Movement time; } \\
\uparrow \uparrow \text { Rest time; } \\
\downarrow \text { Vertical activity }\end{array}$ & [118] \\
\hline
\end{tabular}


Table 1. Cont.

\begin{tabular}{|c|c|c|c|c|c|c|c|c|c|c|}
\hline $\begin{array}{l}\text { Target } \\
\text { (asyn) }\end{array}$ & $\begin{array}{l}\text { Antibody/ } \\
\text { Clone }\end{array}$ & $\underset{\text { (aa) }}{\text { Binding Site }}$ & $\begin{array}{c}\text { Ab Origin } \\
\text { Immunization } \\
\text { Method }\end{array}$ & $\begin{array}{l}\text { Injection } \\
\text { Frequency } \\
\text { Duration } \\
\text { Amount } \\
\end{array}$ & $\begin{array}{l}\text { Animal } \\
\text { Model }\end{array}$ & $\alpha$ syn Pathological Effects & Neuronal Effects & $\begin{array}{c}\text { Other } \\
\text { Non-Neuronal } \\
\text { Effects }\end{array}$ & Behavioral Effects & Ref.s \\
\hline \multirow{6}{*}{$\begin{array}{l}\text { Aggre. } \\
\text { (Oligo/ } \\
\text { Proto- } \\
\text { fibrils) }\end{array}$} & \multirow{6}{*}{$\begin{array}{l}\text { ABBV- } \\
0805 / \mathrm{mAB} 47 \\
\text { for murine } \\
\text { experi- } \\
\text { ments }\end{array}$} & \multirow{6}{*}{$\begin{array}{l}\text { Humanized } \\
\text { mAB47, } \\
\text { binding to } \\
\text { C-term. } \\
121-127\end{array}$} & \multirow{6}{*}{$\begin{array}{l}\text { h- } \alpha \text { syn oligo. } \\
\text {->hybridoma, } \\
\text { same as prior }\end{array}$} & $\begin{array}{l}\text { i.v., bolus, starting at } \\
2 \text { m old, sampled } \\
\text { multiple times. } \\
0.1,1,10 \mathrm{mg} / \mathrm{kg} \\
\end{array}$ & $\begin{array}{c}\text { wt C57BL/6 } \\
\text { mice (phar- } \\
\text { macokinetics) }\end{array}$ & - & $\begin{array}{l}0.3 \% \text { in the brain } \\
\text { dose-dependent plasma } \\
\text { content }\end{array}$ & - & - & \multirow{6}{*}{ [119] } \\
\hline & & & & $\begin{array}{c}\text { i.p., weekly } \\
\text { starting at age } 12 \mathrm{~m} \\
10 \mathrm{mg} / \mathrm{kg}\end{array}$ & $\begin{array}{l}\text { PD: Thy-1- } \\
\text { h[A30P] \&syn } \\
\text { tg mice }\end{array}$ & - & - & - & $\begin{array}{l}\uparrow \text { Mean survival } \\
\text { from } 84 \text { days to } \\
160 \text { days }\end{array}$ & \\
\hline & & & & $\begin{array}{c}\text { i.p., weekly } \\
\text { starting at age } 12 \mathrm{~m}, \\
20 \mathrm{mg} / \mathrm{kg}\end{array}$ & $\begin{array}{l}\text { PD: Thy-1- } \\
\text { h[A30P] } \alpha \text { syn } \\
\text { tg } \\
+10 \mu g \\
\text { gastrocnemius } \\
\text { i.m PFF inj., } \\
\text { after mab } \\
\text { treatment } \\
\end{array}$ & - & - & - & $\begin{array}{l}\uparrow \text { Mean survival } \\
\text { from } 84 \text { days to } 95 \\
\text { days }\end{array}$ & \\
\hline & & & & $\begin{array}{l}\text { Starting } 4 \text { wks prior to } \\
\text { PFF inj.; weekly mab } \\
\text { inj. } \\
\text { Prophylactic: } 2-4 \mathrm{~m}, \\
\text { until severe motor } \\
\text { deficits, } 20 \mathrm{mg} / \mathrm{kg}\end{array}$ & $\begin{array}{l}\text { PD: Thy-1- } \\
\text { h[A30P] \&syn } \\
\text { tg } \\
+ \\
\text { gastrocnemius } \\
\text { PFF inj. } 1 \mu \mathrm{g} \\
\text { i.m. } \\
\end{array}$ & $\begin{array}{c}\downarrow \text { soluble and insoluble } \alpha \text { syn (brain); } \\
\downarrow \text { insoluble pS129- } \alpha \text { syn; } \\
\downarrow \text { CSF pS129- } \alpha \text { syn; } \\
\downarrow \text { LB-509 } \alpha \text { syn inclusions (reticular nucleus); } \\
\downarrow \text { pS129- } \alpha \text { syn inclusion (midbrain). }\end{array}$ & - & - & - & \\
\hline & & & & $\begin{array}{l}\text { Post } 2 \text { wks after PFF } \\
\text { inj.; weekly mab inj. } \\
\text { Therapeutic: } 2-4 \mathrm{~m} \text {. } \\
\text { until severe motor } \\
\text { deficits, } 20 \mathrm{mg} / \mathrm{kg}\end{array}$ & $\begin{array}{l}\text { PD: Thy-1- } \\
\text { h[A30P] asyn } \\
\text { tg } \\
+ \\
\text { gastrocnemius } \\
\text { PFF inj. } 1 \mu \mathrm{g} \\
\text { i.m. }\end{array}$ & 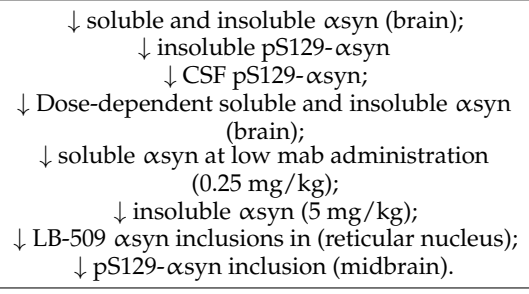 & - & - & - & \\
\hline & & & & $\begin{array}{c}\text { weekly } \\
16 \mathrm{wks} \\
20 \mathrm{mg} / \mathrm{kg}\end{array}$ & $\begin{array}{c}\text { PD: } \\
\text { A53T+/- } \\
\text { mice (83)+ i.c. } \\
\text { (anterior } \\
\text { olfactory } \\
\text { nucleus) PFF } \\
\text { inj. }\end{array}$ & $\begin{array}{l}\downarrow \text { pS129- } \alpha \text { syn pathology spreading to the } \\
\text { contralateral hippocampus (CA1) (58\%). }\end{array}$ & - & - & - & \\
\hline
\end{tabular}

Abbreviations: PFF: preformed fibrils, $\alpha$ syn: alpha-synuclein, FL: full-length, h- $\alpha$ syn: human $\alpha$ syn, CC: Calpain cleaved, pS129-ayn: phosphorylated $\alpha$ syn, phos.: phosphorylated, nitr. nitrated, mab: monoclonal antibodies, mono.: monomeric, oligo.:oligomers/oligomeric, aggre: aggregates/aggregated, m: months, wks: weeks, inj.: injection, i.p.: intraperitoneal, i.m. intramuscular, i.c.: intracerebral, inoc.: inoculation, b.w.: bodyweight, SNpc: substantia nigra pars compacta, tg: transgenic, wt: wild-type, LV: lentivirus. 


\subsection{C-Terminal Targeting Approaches}

The first candidate antibody tested in preclinical models was the monoclonal antibody $(\mathrm{mAb})$ clone 9E4 targeting the C-terminal of human $\alpha$ syn $[106,120]$. The 9E4 murine mAb recognizes the amino acids (aa) 118-126 of human $\alpha$ syn (h $\alpha$ syn) and has been shown to reduce toxic truncated species of $\alpha$ syn, rescued behavioral deficits in PD-GF $\beta$ - $\alpha$ syn transgenic mice and co-localizes with pathology in several brain regions [106]. These results were confirmed again by Masliah's group [18] in the Thy1 $\alpha$ syn (line 61) mice, further expanded to investigate the 9E4 analogs, the 5C1 and 5D12, and the $1 \mathrm{H} 7$ targeting the overlapping region of NAC and C-terminal. The $1 \mathrm{H} 7$ and $5 \mathrm{C} 1$ showed comparable decreased toxic $\alpha$ syn truncated species, proposed to be reduced by internalization and lysosomal degradation [106], as well as improved behavioral deficits and protected tyrosine hydroxylase (TH) cell loss [18]. The $1 \mathrm{H} 7 \mathrm{mAb}$ was further investigated in Thy1 $\alpha$ syn (line 61) mice, laterally injected with human $\alpha$ syn expressing Lentivirus [112]. The $1 \mathrm{H} 7$ reduced axonal aggregation of $\alpha$ syn and protected axonal integrity, as well as improved memory deficits and increased colocalization of $\alpha$ syn and Iba- 1 positive microglia, suggestive for microglia phagocytosis of extracellular $\alpha$ syn [112]. The main difference is that $1 \mathrm{H} 7$ preferably binds aggregated $\alpha$ syn at the C-terminus but also monomers. Following the results of Masliah and colleagues [112,120], targeting the C-terminal has become an optimistic immunization targeting strategy. Thus, several other antibodies have been produced targeting the C-terminus of $\alpha$ syn. Parallel to the $9 \mathrm{E} 4 \mathrm{mAb}$, another $\mathrm{mAb}$ targeting the $\mathrm{C}$-terminal, the Ab274, was additionally investigated in collaboration between Masliah, Seung-Jae Lee and colleagues [107]. The Ab274, a IgG2a murine mAb, was investigated in PD-GF $\beta$ - $\alpha$ syn mice (line $\mathrm{M}$ ) showing reduced $\alpha$ syn in cortical and limbic brain regions by microglial phagocytosis, additionally improving behavioral deficits [107]. Two other mAbs have been produced to target the C-terminal of $\alpha$ syn, the Syn211 [108] and AB2 [110]. The Syn211 was tested in wild-type (wt) mice with intrastriatal injection of preformed $\alpha$ syn fibrils (PFFs) and reduced insoluble $\alpha$ syn and phosphorylated $\alpha$ syn aggregates [108]. The AB2 mAb similarly reduced $\alpha$ syn in brain homogenates in nigral $\alpha$ syn-overexpressing wt rats [110].

\subsection{N-Terminal and NAC Targeting Approaches}

Interestingly, Tran and Shahaduzzaman tested an N-terminal-targeting antibody in parallel: Syn303 (aa 1-5) [108] and AB1 (aa 16-35) [110]. It seemed that the mAbs targeting the N-terminal surpassed the effects of the C-terminal targeting mAbs. In addition to overall reduced $\alpha$ syn levels, the Syn303 reduced $\alpha$ syn spread in the SNpc with $30 \%$ and in the ipsilateral and contralateral amygdala with $40 \%$, and further improved motoric deficits [108]. However, in a later study, Syn303 was found inferior to their novel syn9048 $\mathrm{mAb}$ targeting the C-terminal and preferably binding aggregated $\alpha$ syn structures [116]. The N-terminal-targeting AB1 additionally reduced DA and NeuN cell loss [110]. Very recently Chen and colleagues [118] (Chen et al., 2021) conducted a preclinical study using a NAC-targeting mAb (NAC32), which showed reduced $\alpha$ syn pathology in the SN (25\%), prevented $\mathrm{TH}+$ neuron degradation and further reduced behavioral deficits [118]. Targeting monomeric (soluble non-toxic) $\alpha$ syn proposes a different challenge, as reduction of functional $\alpha$ syn potentially could harm normal physiological properties. After all, studies investigating $\alpha$ syn knock-out or knock-down have shown aberrant dopamine synthesis and release, and even dopaminergic degeneration [121], and potential other physiological functions. It is therefore of utmost importance to ensure that $\mathrm{mAbs}$ targeting monomeric non-toxic $\alpha$ syn do not negatively affect normal dopamine synthesis and/or its release. A way to circumvent this challenge is to target extracellular toxic $\alpha$ syn conformers.

\subsection{Conformational Targeting Approaches}

Numerous antibodies have been developed targeting different $\alpha$ syn conformational structures, from small oligomeric to larger fibrillary structures. Lindstrøm and colleagues [109] were the first to report on a mAb selective for conformational $\alpha$ syn struc- 
tures, this mAB47 is an IgG1 mAb which only reduces $\alpha$ syn protofibrils in the spinal cord, but not in the brain, of Thy-1-H[A30P] mice [122]. Kallab and colleagues [113] later worked with a different clone of mAB47, called Rec47, in an MSA mouse model, the PLP- $\alpha$ syn tg mouse model, which, in contrast to Lindstrøm and colleagues [109], showed reduced microglia signal and reduced activated microglial cells, correlated to reduced oligomeric asyn. Furthermore, they observed reduced GCIs in the spinal cord, colocalization of phosphorylated $\alpha$ syn pathology and correlation between Iba- 1 positive microglia and oligomeric $\alpha$ syn. They suggested an autophagy-directed elimination of $\alpha$ syn [113]. Very recently, Nordström and colleagues thoroughly investigated the mAb47 (murine version of ABBV0805), firstly establishing the binding region of the mAb to the C-terminal (121-127 aa) of $\alpha$ syn, but more selective for aggregated $\alpha$ syn species [119]. Nordström and colleagues extensively evaluated $\mathrm{mAb} 47$ in three different PD mice models with and without injection of preformed fibrils (to induce seeding) in both a prophylactic and therapeutic manner. They observed in wt mice, as well as in Thy-1-h[A30P] mice injected with $10 \mu \mathrm{g}$ fibrils in the gastrocnemius muscle, a prolonged survival with the mAb47 treatment. In a Thy1-h[A30P] mice injected with $1 \mu \mathrm{g}$ fibrils, they further observed a reduced soluble and insoluble $\alpha$ syn in the brain and reduced levels of phosphorylated $\alpha$ syn in the CSF in both a prophylactic and therapeutic regime. Moreover, both soluble and insoluble levels were reduced in the brain in a dose-dependent administration of $\mathrm{mAb} 47$, more effective towards soluble $\alpha$ syn. Lastly, they investigated the efficacy of mAb47 in an A53T+/- intracerebral fibril-seeding mice model with fibril injection into the anterior olfactory nucleus. After 16 weeks of weekly mAb47 intraperitoneal administration, spreading of phosphorylated $\alpha$ syn was reduced in the CA1 hippocampal region [119]. El-Agnaf and colleagues studied three antibodies selective for oligomers and aggregates (Syn-01, Syn-02 and Syn-04) and two for mature aggregates (Syn-F1 and Syn-F2) [111]. Weekly injections over a 3-month period in mThy1 asyn (line 61) mice showed that the Syn01, Syn-04 and Syn-F1 exhibit an overall similar effect by reducing $\alpha$ syn in central brain regions (striatum, $\mathrm{SN}$, and neocortex). Moreover, they reduced total $\alpha$ syn, oligomeric $\alpha$ syn and Syn-01, Syn02 and Syn-04 also reduced 5G4-aggregated $\alpha$ syn. Only the Syn-01, Syn-04 and Syn-F1 rescued neuronal degradation and behavioral deficits. Syn-01 and Syn-04 further reduced astroand microgliosis [111]. As for the 1H7, Schofield and colleagues from AstraZeneca among others developed a high-affinity monoclonal anti- $\alpha$ syn antibody, MEDI1341, which binds the C-terminal monomeric form and aggregated $\alpha$ syn [114]. Weekly administration of MEDI1341 in mThy1 $\alpha$ syn mice with intra-hippocampal $\alpha$ syn injections [112], reduced asyn in hippocampal and neocortical areas [114]. As mentioned, Henderson and colleagues [116] tested the preferred binding of the novel Syn9048 mAb. Comparable to the previously tested mAb, Syn303 [108], Henderson et al. demonstrated reduced spread of asyn pathology in the brain and attenuated dopamine reductions in the striatum of $\mathrm{wt}$ mice with PFF unilateral injection in the dorsal striatum [116]. Huang and colleagues used a different approach, isolating anti- $\alpha$ syn $n A b s$ from IViG using column chromatography, and administered them weekly at low $(0.8 \mathrm{mg} / \mathrm{kg})$ and at high $(2.4 \mathrm{mg} / \mathrm{kg})$ dosages in a A53T transgenic PD mouse model [115]. In both low and high dosages Huang and colleagues showed that nAbs reduced phosphorylated $\alpha$ syn and soluble $\alpha$ syn in the brainstem. Both dosages reduced astrocytes in the striatum and increased $\alpha$ syn and microglia co-localization, as well as rescued motoric deficits. The rescuing effects were shown to be effective in a dose-dependent manner, with further reduced phosphorylated $\alpha$ syn in cortical areas and reduced total human insoluble, soluble and oligomeric $\alpha$ syn as in the brainstem. The effect of higher dosage further rescued behavioral deficits, in addition to the rescuing effect of pathological alterations e.g., reduced activated microglia and rescued $\mathrm{TH}+$ positive neurons among others [115]. The BIIB054, also called cinpanemab, is a monoclonal mAb targeting the N-terminal (aa 1-10) with 800-fold greater affinity towards aggregated asyn produced by Weihofen and colleagues in collaboration between Biogen Ltd. and Neurimmune AG Ltd. [117]. Weihofen and colleagues tested the BIIB054 in three different mouse models: (1) in female wt seeded contralateral with fibrils, they observed reduced 
truncated $\alpha$ syn at 100 days and improved hangwire test at 60 days; (2) in male transgenic A53T mice (M83) seeded with fibrils in the striatum, they showing less severe paralysis at day 5, reduced paralysis at day 7 and weight loss at day 9; and (3) in male and female fibril-seeded BAC $\alpha$ syn A53T mice [123], they reported rescuing effects of the contralateral DAT signal at 90 days post seeding [117].

Huang and Weihofen investigated $\alpha$ syn-specific IViG nAbs and the BIIB054 mAb respectively [115,117], and both incorporate the idea that healthy individuals have antibodies resisting pathology. Huang and colleagues isolated anti- $\alpha$ syn nAbs from IViG, containing immunoglobulins gathered from a large healthy population [115]. Weihofen and colleagues went a step further, investigating the paratopes from a repertoire of B cell receptors (BCRs) from healthy individuals and produced $\alpha$ syn-specific nAbs from the repertoire [117]. In both studies, the nAbs showed significant rescuing effects in preclinical animal PD models. Table 1 shows an overview of PD animal studies investigating the different passive immunization strategies.

\subsection{Passive Candidates Translated into Clinical Trials}

Of the preclinical evaluated passive immunization candidates, a few have been translated into clinical trials (Table 2). Prasinezumab (PRX002) is a humanized IgG1 antibody from the murine version of 9E4 $[18,106]$. Although it did not meet its primary outcome (MDS-UPDRS), the antibody significantly showed decline on the UPDRS-III and patients with fast progressive and severe symptoms benefited more from the treatment and is currently running phase II, the PASADENA study. The second antibody tested in clinical trials is the mAB47or rec47 [109,113], now called ABBV-0805, however, the company AbbVie cancelled the phase Ib trial due to strategic reasons. MEDI1341 from AstraZeneca and Takeda Pharmaceuticals are currently running its phase $\mathrm{Ib}$ in early PD patients; the study will run into 2022. BIIB054, also called Cinpanemab, classified as a human-derived mAb made through reverse translational engineering, started a large phase II study, SPARK, but halted the development of Cinpanemab after it missed its primary and secondary endpoint. A fourth mAb, called LU AF82422, a humanized IgG1 monoclonal antibody, did not report any preclinical report, and no results from its phase I study are available yet. However, they recently released a phase II initiation press release.

Table 2. Passive immunization candidates currently in clinical trials.

\begin{tabular}{|c|c|c|c|c|c|c|c|}
\hline Target ( $\alpha$ syn) & Name & Companies & Antibody/Clone & Binding Site (aa) & Clinical Groups & $\begin{array}{c}\text { Current Clinical } \\
\text { Phase }\end{array}$ & Clinical Trial ID \\
\hline Aggre. & $\begin{array}{c}\text { PRX002/ } \\
\text { (Prasinezumab)- } \\
\text { PASADENA } \\
\text { study }\end{array}$ & $\begin{array}{l}\text { Hoffman-La } \\
\text { Roche; Prothena } \\
\text { Biosciences } \\
\text { Limited. }\end{array}$ & $\begin{array}{l}\text { Humanized IgG1 } \\
\text { mab version of } \\
\text { murine 9E4 }\end{array}$ & $\begin{array}{c}\text { Preferable } \\
\text { aggregated } \alpha \text { syn } \\
\text { within the } \\
\text { C-terminal at aa } \\
118-126 \\
\text { (VDPDNEAYE) }\end{array}$ & $\begin{array}{l}\text { PD patients } \\
(\mathrm{H} \& Y<2)\end{array}$ & $\begin{array}{l}\text { Phase II; } \\
\text { active; } \\
\text { recruitment } \\
\text { completed. }\end{array}$ & NCT03100149 \\
\hline $\begin{array}{l}\text { Aggre. } \\
\text { (Oligo/proto- } \\
\text { fibrils) }\end{array}$ & ABBV-0805 & $\begin{array}{c}\text { AbbVie; } \\
\text { BioArctic } \\
\text { Neuroscience AB }\end{array}$ & $\begin{array}{l}\text { Humanized } \\
\text { mAB47 mab }\end{array}$ & $\begin{array}{c}\text { Preferable } \\
\text { aggregated } \alpha \text { syn } \\
\text { within the } \\
\text { C-terminal at aa } \\
121-127 \\
\text { (DNEAYEM) }\end{array}$ & $\begin{array}{l}\text { PD patients } \\
(<5 \text { years from } \\
\text { diagnosis and } \\
H \& Y<3)\end{array}$ & $\begin{array}{l}\text { Phase I; } \\
\text { recruiting. }\end{array}$ & NCT04127695 \\
\hline Aggre. & MEDI1341 & $\begin{array}{c}\text { Astra Zeneca; } \\
\text { Takeda } \\
\text { Pharmaceuticals }\end{array}$ & $\begin{array}{l}\text { Humanized IgG1 } \\
\text { mab }\end{array}$ & $\begin{array}{c}\text { Preferable } \\
\text { aggregated } \alpha \text { syn } \\
\text { within the } \\
\text { C-terminal } \\
\text { (within the aa } \\
103-129 \text { region) }\end{array}$ & $\begin{array}{c}\text { Healthy } \\
\text { individuals } \\
\text { (MEDI1341 vs. } \\
\text { placebo) }\end{array}$ & $\begin{array}{l}\text { Phase I; } \\
\text { recruitment } \\
\text { completed. }\end{array}$ & NCT03272165 \\
\hline Aggre. & $\begin{array}{l}\text { BIIB054 } \\
\text { (Cinpanemab)- } \\
\text { SPARK } \\
\text { study }\end{array}$ & $\begin{array}{c}\text { Biogen; } \\
\text { Neuroimmune }\end{array}$ & $\begin{array}{l}\text { Healthy human } \\
\text { memory B cells } \\
\text { derived mab }\end{array}$ & $\begin{array}{c}\text { Preferable } \\
\text { aggregated } \\
\alpha \text { syn, oxidized } \\
\text { at N-terminal aa: } \\
4-10 \\
\text { (FMKGLSK) }\end{array}$ & $\begin{array}{l}\text { PD patients } \\
(<3 \text { years from } \\
\text { diagnosis and } \\
H \& Y<2.5)\end{array}$ & $\begin{array}{c}\text { Phase II; } \\
\text { Terminated }\end{array}$ & NCT03318523 \\
\hline
\end{tabular}


Table 2. Cont.

\begin{tabular}{|c|c|c|c|c|c|c|c|}
\hline Target ( $\alpha$ syn) & Name & Companies & Antibody/Clone & Binding Site (aa) & Clinical Groups & $\begin{array}{c}\text { Current Clinical } \\
\text { Phase }\end{array}$ & Clinical Trial ID \\
\hline Aggre. & $\begin{array}{l}\text { Lu AF82422- } \\
\text { AMULET } \\
\text { study }\end{array}$ & $\begin{array}{c}\text { H. Lundbeck } \\
\text { A/S; } \\
\text { Genmab A/S }\end{array}$ & $\begin{array}{l}\text { Humanized IgG1 } \\
\text { mab }\end{array}$ & $\begin{array}{c}\text { Preferable } \\
\text { aggregated } \alpha \text { syn } \\
\text { within the } \\
\text { C-terminal at aa } \\
112-117 \\
\text { (ILEDMP) }\end{array}$ & $\begin{array}{c}\text { MSA-P and } \\
\text { MSA-C patients } \\
\text { (<5 years from } \\
\text { diagnosis, } \\
\text { UMSARS } \leq 16, \\
\text { MoCA } \geq 22)\end{array}$ & $\begin{array}{l}\text { Phase II; } \\
\text { recruiting }\end{array}$ & NCT05104476 \\
\hline
\end{tabular}

Abbreviations: $\alpha$ syn: alpha-synuclein, mab: monoclonal antibodies, aggre: aggregates/aggregated, aa: amino acids, oligo: oligomers/oligomeric.

\section{Towards Personalized Immunotherapy}

Several mechanisms have been implicated to trigger the initiation of pathogenic $\alpha$ syn in the gut. Besides regulating the uptake of nutrients and water, the gut also provides an essential barrier against harmful or toxic substances from the external environment entering the body. About $400 \mathrm{~m}^{2}$ of gut internal membranes are exposed to environmental factors, compared to $\sim 2 \mathrm{~m}^{2}$ of total skin surface area, meaning the gut is the main organ protecting against exposure to foreign pathogens [124]. It has been shown that bacterial and environmental toxins that enter the gut lumen can cause disruption of the intestinal epithelial barrier [125], alter the gut microbiome [126] and cause mucosal inflammation and oxidative stress $[127,128]$. A complex interplay of these factors are then able to trigger $\alpha$ syn misfolding in the gut plexi, and an increased permeability of the intestinal barrier or 'leaky gut' will ultimately provide a route of transmission for the gut-formed $\alpha$ syn seeds to the brain [78]. These findings indicate the gut as an important target for passive immunization therapy for two reasons. Early intervention in prodromal disease stages of gut-first cases may halt formation of pathogenic $\alpha$ syn and subsequent gut-to-brain propagation. Second, only $0.1-0.2 \%$ of nAbs cross the blood-brain barrier. Therefore, it is conceivable that immunotherapy in prodromal patients with 'leaky gut' could be more effective. Increased gut permeability in prodromal patients with leaky gut might yield a better uptake of the administered nAbs near the source of pathogenic $\alpha$ syn, resulting in a better treatment efficacy, as opposed to brain-first cases where the source is located in the brain (see Figure 2). Body-first PD patients are characterized by a more rapidly progressing phenotype, with faster motor and non-motor progression and more rapid cognitive decline, compared to brain-first PD patients $[15,90]$. This might explain why patients with fast progressive and severe symptoms benefited most from the treatment with Prasinezumab in the clinical trial. The validity of the SOC model requires further investigation, esp. in the prodromal phase. Detailed phenotyping of non-iRBD prodromal (i.e., brain-first subtype) patients is not yet available. Therefore, fundamental questions remain to be addressed: how these subtypes differ in their disease initiation mechanisms and progression patterns (esp. in the prodromal phase), and how such knowledge could be exploited for tailored subtype-specific immunotherapy. Future animal models should take into account varying disease onset sites to obtain causal and mechanistic understanding of the body-brain link in different disease subtypes, and to discover subtype-specific targets for immunotherapy. Recently developed, more sensitive, investigative tools such as PMCA (Protein-Misfolding Cyclic Amplification), RT-QuIC (Real-Time Quaking-Induced Conversion), PLA (Proximity Ligation Assay) and thiophene-based assays should be included while studying synucleinopathies to investigate the relation between disease onset site and subtype-specific strain characteristics. The identification of subtype-specific $\alpha$ syn aggregates in easily accessible peripheral fluids or tissues from brain-first or body-first cases may enable early stratification as well as development of subtype-specific nAbs for immunotherapy. 


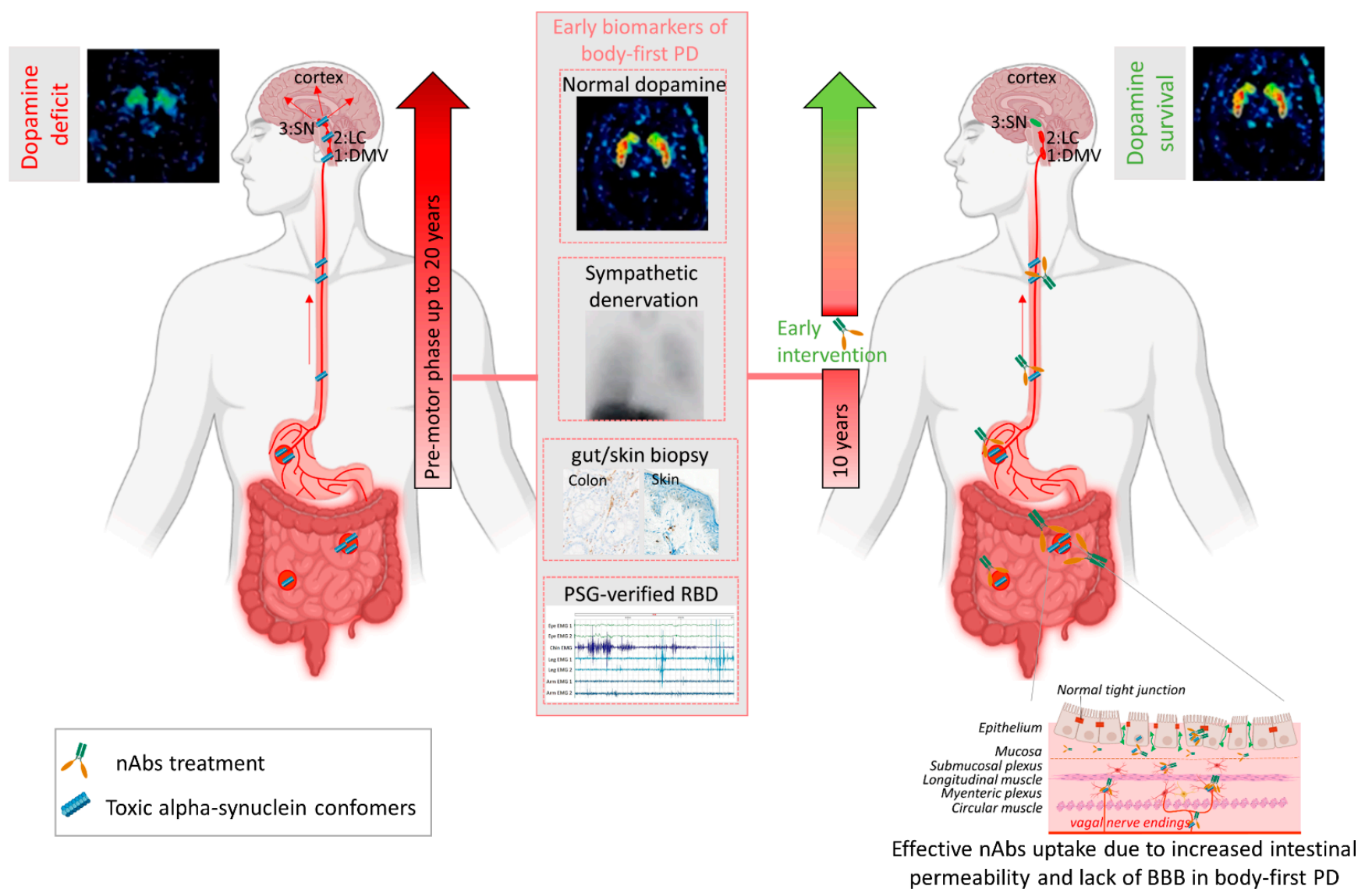

Figure 2. Passive immunization of pre-motor body-first PD patients enhances dopamine survival. Patients with probable prodromal body-first PD could be identified by a combination of several early biomarkers, such as the presence of pathological alpha-synuclein ( $\alpha$ syn) in skin and/or gut biopsies, polysomnography-verified RBD, cardiac sympathetic denervation on MIBG scintigraphies, but normal or near-normal nigrostriatal dopaminergic innervation on DaT SPECT. Such detailed phenotyping in the pre-motor phase might reveal body-first PD, allowing early intervention and optimal patient selection for clinical trials. Pre-motor start of nAbs treatment increases treatment efficacy by delaying or blocking peripheral-to-brain propagation of pathology, before any irreversible damage to the dopamine system is done, hereby enhancing the probability of dopamine survival in body-first PD. Furthermore, increased gut permeability in prodromal body-first PD patients with 'leaky gut' or increased intestinal permeability might yield a better uptake of the administered nAbs near the source of pathogenic $\alpha$ syn conformers, resulting in a better treatment efficacy, as opposed to brain-first cases where the source is located in the brain and only $0.1-0.2 \%$ of nAbs cross the blood-brain barrier. Abbreviations: nAbs: naturally occurring autoantibodies; DMV: dorsal motor nucleus of the vagus; LC: locus coeruleus; SN: substantia nigra, PAF: pure autonomic failure, PSG: polysomnography, BBB: blood brain barrier. Created using Biorender.com (accessed on 30 November 2021).

Future clinical studies should focus on detailed imaging-based phenotyping for accurate stratification of prodromal disease subtypes, as careful patient selection for clinical trials will likely increase treatment efficacy and translation ability of preclinical studies. An $\alpha$ syn PET tracer would allow for early stratification and detailed investigation and follow-up of synucleinopathy subtypes. Until that is discovered, a combination of other biomarkers should be used. The gut and skin, as well as blood and CSF, are easily accessible for biopsy studies to detect and quantify (subtype-specific) $\alpha$ syn. Using ultra-sensitive methods, such as PMCA or RT-QuIC, on these biopsies, could contribute to an a priori screening of patients with toxic prion-like $\alpha$ syn phenotype. This could provide not only more personalized interventions, but also plan for more effective clinical trials with minus- 
asyn PD patients, as proposed to be the case in Parkin and LRRK2 mutation carriers [129]. Furthermore, in combination with imaging techniques, such as a DaT brain scan, MIBG heart scan and donepezil gut scan, this may enable prodromal diagnosis, together with quantification of non-motor symptoms such as RBD (polysomnography), gastrointestinal transit time (radio opaque markers [130], orthostatic hypotension and dementia (cognition test). Detailed imaging-based and $\alpha$ syn templating-positive phenotyping is of significant importance to identify patients in the earliest phase of the disease, but also to evaluate treatment effects of immunotherapy (see Figure 2). Nevertheless, the road to use immune-based therapies on the basis of a priori preselected individuals is still long and cumbersome.

\section{Future Perspectives and Conclusions}

nAbs targeting soluble monomeric $\alpha$ syn may affect dopamine synthesis negatively; therefore, it is preferred to target extracellular toxic insoluble $\alpha$ syn conformers. Numerous antibodies have been developed targeting different $\alpha$ syn conformers, ranging from small oligomeric to larger fibrillar structures. Preclinical studies have shown significant rescuing effects of nAbs treatment in PD animal models. Of the preclinical evaluated passive immunization candidates, a few have been translated into clinical trials, with suboptimal results, probably due to suboptimal patient selection with a mix of different PD phenotypes that are mainly situated in advanced disease stages. To improve treatment efficacy, a combination of imaging-based and histology-based biomarkers should be employed to identify body-first synucleinopathies in the earliest stages. Early immunization of these patients will prevent body-to-brain spread of pathology prior to irreversible dopamine damage in the brain. Current nAbs have been evaluated solely in brain-first animal models of synucleinopathies. In the future, animal models of body-first synucleinopathies should be employed to validate new and existing nAbs candidates. Such studies should investigate the potential of nAbs treatment to slow down or block accumulation of pathology in peripheral organs and subsequent spread through the entire autonomic connectome, as well as its potential rescuing effect on associated synaptic and neuronal dysfunction.

Funding: Nathalie Van Den Berge is funded by the Lundbeck Foundation (R322-2019-2544), Jascha Foundation, Danish Parkinson's Association and Bjarne Saxhofs fond. Jonas Folke is funded by the Danish Independent Research Fund and Danish Parkinson's Association.

Institutional Review Board Statement: Not applicable.

Informed Consent Statement: Not applicable.

Data Availability Statement: Not applicable.

Acknowledgments: We thank Niels Okkels (Department of Nuclear Medicine and PET, Aarhus University Hospital) for providing us with representative PSG data of an RBD patient. The skin sample of the PAF patient was kindly provided by Páll Karlsson (Department of Clinical Medicine, Aarhus University) and Astrid Juhl Terkelsen (Department of Neurology, Aarhus University Hospital).

Conflicts of Interest: The authors declare no conflict of interest.

\section{References}

1. Spillantini, M.G.; Schmidt, M.L.; Lee, V.M.; Trojanowski, J.Q.; Jakes, R.; Goedert, M. Alpha-synuclein in Lewy bodies. Nature 1997, 388, 839-840. [CrossRef]

2. Polymeropoulos, M.H.; Lavedan, C.; Leroy, E.; Ide, S.E.; Dehejia, A.; Dutra, A.; Pike, B.; Root, H.; Rubenstein, J.; Boyer, R.; et al. Mutation in the alpha-synuclein gene identified in families with Parkinson's disease. Science 1997, 276, 2045-2047. [CrossRef]

3. Chartier-Harlin, M.-C.; Kachergus, J.; Roumier, C.; Mouroux, V.; Douay, X.; Lincoln, S.; Levecque, C.; Larvor, L.; Andrieux, J.; Hulihan, M.; et al. Alpha-synuclein locus duplication as a cause of familial Parkinson's disease. Lancet 2004, 364, 1167-1169. [CrossRef]

4. $\quad$ Singleton, A.B.; Farrer, M.; Johnson, J.; Singleton, A.; Hague, S.; Kachergus, J.; Hulihan, M.; Peuralinna, T.; Dutra, A.; Nussbaum, R.; et al. alpha-Synuclein locus triplication causes Parkinson's disease. Science 2003, 302, 841. [CrossRef]

5. Visanji, N.P.; Lang, A.E.; Kovacs, G.G. Beyond the synucleinopathies: Alpha synuclein as a driving force in neurodegenerative comorbidities. Transl. Neurodegener. 2019, 8, 28. [CrossRef] 
6. Papp, M.I.; Kahn, J.E.; Lantos, P.L. Glial cytoplasmic inclusions in the CNS of patients with multiple system atrophy (striatonigral degeneration, olivopontocerebellar atrophy and Shy-Drager syndrome). J. Neurol. Sci. 1989, 94, 79-100. [CrossRef]

7. Jellinger, K.A.; Lantos, P.L. Papp-Lantos inclusions and the pathogenesis of multiple system atrophy: An update. Acta Neuropathol. 2010, 119, 657-667. [CrossRef]

8. Kovacs, G.G. Molecular Pathological Classification of Neurodegenerative Diseases: Turning towards Precision Medicine. Int. J. Mol. Sci. 2016, 17, 189. [CrossRef]

9. Armstrong, M.J.; Emre, M. Dementia with Lewy bodies and Parkinson disease dementia: More different than similar? Neurology 2020, 94, 858-859. [CrossRef]

10. Borghammer, P. How does parkinson's disease begin? Perspectives on neuroanatomical pathways, prions, and histology. Mov. Disord. 2018, 33, 48-57. [CrossRef]

11. Beach, T.G.; Adler, C.H.; Sue, L.I.; Vedders, L.; Lue, L.; White Iii, C.L.; Akiyama, H.; Caviness, J.N.; Shill, H.A.; Sabbagh, M.N.; et al. Multi-organ distribution of phosphorylated alpha-synuclein histopathology in subjects with Lewy body disorders. Acta Neuropathol. 2010, 119, 689-702. [CrossRef] [PubMed]

12. Mendoza-Velásquez, J.J.; Flores-Vázquez, J.F.; Barrón-Velázquez, E.; Sosa-Ortiz, A.L.; Illigens, B.-M.W.; Siepmann, T. Autonomic Dysfunction in $\alpha$-Synucleinopathies. Front. Neurol. 2019, 10, 363. [CrossRef]

13. Thaisetthawatkul, P. Pure Autonomic Failure. Curr. Neurol. Neurosci. Rep. 2016, 16, 74. [CrossRef] [PubMed]

14. Palma, J.-A.; Norcliffe-Kaufmann, L.; Kaufmann, H. Diagnosis of multiple system atrophy. Auton. Neurosci. 2018, 211, 15-25. [CrossRef]

15. Borghammer, P. The $\alpha$-Synuclein Origin and Connectome Model (SOC Model) of Parkinson's Disease: Explaining Motor Asymmetry, Non-Motor Phenotypes, and Cognitive Decline. J. Parkinsons. Dis. 2021, 11, 455-474. [CrossRef]

16. Borghammer, P.; Horsager, J.; Andersen, K.; Van Den Berge, N.; Raunio, A.; Murayama, S.; Parkkinen, L.; Myllykangas, L. Neuropathological evidence of body-first vs. brain-first Lewy body disease. Neurobiol. Dis. 2021, 161, 105557. [CrossRef] [PubMed]

17. Albus, A.; Jördens, M.; Möller, M.; Dodel, R. Encoding the Sequence of Specific Autoantibodies Against beta-Amyloid and alpha-Synuclein in Neurodegenerative Diseases. Front. Immunol. 2019, 10, 2033. [CrossRef] [PubMed]

18. Games, D.; Valera, E.; Spencer, B.; Rockenstein, E.; Mante, M.; Adame, A.; Patrick, C.; Ubhi, K.; Nuber, S.; Sacayon, P.; et al. Reducing C-terminal-truncated $\alpha$-synuclein by immunotherapy attenuates neurodegeneration and propagation in Parkinson's disease-like models. J. Neurosci. 2014, 34, 9441-9454. [CrossRef]

19. Bergström, A.L.; Kallunki, P.; Fog, K. Development of Passive Immunotherapies for Synucleinopathies. Mov. Disord. 2015, 31, 16-21. [CrossRef]

20. Antonini, A.; Bravi, D.; Sandre, M.; Bubacco, L. Immunization therapies for Parkinson's disease: State of the art and considerations for future clinical trials. Expert Opin. Investig. Drugs 2020, 29, 685-695. [CrossRef]

21. Li, X.; Koudstaal, W.; Fletcher, L.; Costa, M.; van Winsen, M.; Siregar, B.; Inganäs, H.; Kim, J.; Keogh, E.; Macedo, J.; et al. Naturally occurring antibodies isolated from PD patients inhibit synuclein seeding in vitro and recognize Lewy pathology. Acta Neuropathol. 2019, 137, 825-836. [CrossRef]

22. Scott, K.M.; Kouli, A.; Yeoh, S.L.; Clatworthy, M.R.; Williams-Gray, C.H. A Systematic Review and Meta-Analysis of Alpha Synuclein Auto-Antibodies in Parkinson's Disease. Front. Neurol. 2018, 9, 815. [CrossRef]

23. Brudek, T.; Winge, K.; Folke, J.; Christensen, S.; Fog, K.; Pakkenberg, B.; Pedersen, L.O. Autoimmune antibody decline in Parkinson's disease and Multiple System Atrophy; a step towards immunotherapeutic strategies. Mol. Neurodegener. 2017, 12, 44. [CrossRef]

24. Folke, J.; Rydbirk, R.; Løkkegaard, A.; Salvesen, L.; Hejl, A.-M.; Starhof, C.; Bech, S.; Winge, K.; Christensen, S.; Pedersen, L.Ø.; et al. Distinct Autoimmune Anti- $\alpha$-Synuclein Antibody Patterns in Multiple System Atrophy and Parkinson's Disease. Front. Immunol. 2019, 10, 2253. [CrossRef]

25. Folke, J.; Rydbirk, R.; Løkkegaard, A.; Hejl, A.-M.; Winge, K.; Starhof, C.; Salvesen, L.; Pedersen, L.Ø.; Aznar, S.; Pakkenberg, B.; et al. Cerebrospinal fluid and plasma distribution of anti- $\alpha$-synuclein IgMs and IgGs in multiple system atrophy and Parkinson's disease. Parkinsonism Relat. Disord. 2021, 87, 98-104. [CrossRef]

26. Chartier, S.; Duyckaerts, C. Is Lewy pathology in the human nervous system chiefly an indicator of neuronal protection or of toxicity? Cell Tissue Res. 2018, 373, 149-160. [CrossRef]

27. Ingelsson, M. Alpha-Synuclein Oligomers-Neurotoxic Molecules in Parkinson's Disease and Other Lewy Body Disorders. Front. Neurosci. 2016, 10, 408. [CrossRef]

28. Maroteaux, L.; Campanelli, J.T.; Scheller, R.H. Synuclein: A neuron-specific protein localized to the nucleus and presynaptic nerve terminal. J. Neurosci. 1988, 8, 2804-2815. [CrossRef]

29. George, J.M. The synucleins. Genome Biol. 2002, 3, reviews3002. [CrossRef]

30. Stefanis, L. $\alpha$-Synuclein in Parkinson's disease. Cold Spring Harb. Perspect. Med. 2012, 2, a009399. [CrossRef]

31. Vargas, K.J.; Makani, S.; Davis, T.; Westphal, C.H.; Castillo, P.E.; Chandra, S.S. Synucleins regulate the kinetics of synaptic vesicle endocytosis. J. Neurosci. 2014, 34, 9364-9376. [CrossRef]

32. Logan, T.; Bendor, J.; Toupin, C.; Thorn, K.; Edwards, R.H. $\alpha$-Synuclein promotes dilation of the exocytotic fusion pore. Nat. Neurosci. 2017, 20, 681-689. [CrossRef] [PubMed] 
33. Danzer, K.M.; Haasen, D.; Karow, A.R.; Moussaud, S.; Habeck, M.; Giese, A.; Kretzschmar, H.; Hengerer, B.; Kostka, M. Different species of alpha-synuclein oligomers induce calcium influx and seeding. J. Neurosci. 2007, 27, 9220-9232. [CrossRef] [PubMed]

34. Bartels, T.; Choi, J.G.; Selkoe, D.J. $\alpha$-Synuclein occurs physiologically as a helically folded tetramer that resists aggregation. Nature 2011, 477, 107-110. [CrossRef] [PubMed]

35. Wang, W.; Perovic, I.; Chittuluru, J.; Kaganovich, A.; Nguyen, L.T.T.; Liao, J.; Auclair, J.R.; Johnson, D.; Landeru, A.; Simorellis, A.K.; et al. A soluble $\alpha$-synuclein construct forms a dynamic tetramer. Proc. Natl. Acad. Sci. USA 2011, 108, 17797-17802. [CrossRef]

36. Dong, C.; Hoffmann, M.; Li, X.; Wang, M.; Garen, C.R.; Petersen, N.O.; Woodside, M.T. Structural characteristics and membrane interactions of tandem $\alpha$-synuclein oligomers. Sci. Rep. 2018, 8, 6755. [CrossRef]

37. Trexler, A.J.; Rhoades, E. N-Terminal acetylation is critical for forming $\alpha$-helical oligomer of $\alpha$-synuclein. Protein Sci. 2012, 21, 601-605. [CrossRef] [PubMed]

38. Iyer, A.; Roeters, S.J.; Schilderink, N.; Hommersom, B.; Heeren, R.M.A.; Woutersen, S.; Claessens, M.M.A.E.; Subramaniam, V. The Impact of N-terminal Acetylation of $\alpha$-Synuclein on Phospholipid Membrane Binding and Fibril Structure. J. Biol. Chem. 2016, 291, 21110-21122. [CrossRef]

39. Rossetti, G.; Musiani, F.; Abad, E.; Dibenedetto, D.; Mouhib, H.; Fernandez, C.O.; Carloni, P. Conformational ensemble of human $\alpha$-synuclein physiological form predicted by molecular simulations. Phys. Chem. Chem. Phys. 2016, 18, 5702-5706. [CrossRef]

40. Giasson, B.I.; Murray, I.V.; Trojanowski, J.Q.; Lee, V.M. A hydrophobic stretch of 12 amino acid residues in the middle of alpha-synuclein is essential for filament assembly. J. Biol. Chem. 2001, 276, 2380-2386. [CrossRef]

41. Kara, E.; Lewis, P.A.; Ling, H.; Proukakis, C.; Houlden, H.; Hardy, J. $\alpha$-Synuclein mutations cluster around a putative protein loop. Neurosci. Lett. 2013, 546, 67-70. [CrossRef] [PubMed]

42. Lázaro, D.F.; Rodrigues, E.F.; Langohr, R.; Shahpasandzadeh, H.; Ribeiro, T.; Guerreiro, P.; Gerhardt, E.; Kröhnert, K.; Klucken, J.; Pereira, M.D.; et al. Systematic comparison of the effects of alpha-synuclein mutations on its oligomerization and aggregation. PLoS Genet. 2014, 10, e1004741. [CrossRef]

43. Bengoa-Vergniory, N.; Roberts, R.F.; Wade-Martins, R.; Alegre-Abarrategui, J. Alpha-synuclein oligomers: A new hope. Acta Neuropathol. 2017, 134, 819-838. [CrossRef]

44. Braak, H.; Del Tredici, K.; Rüb, U.; de Vos, R.A.I.; Jansen Steur, E.N.H.; Braak, E. Staging of brain pathology related to sporadic Parkinson's disease. Neurobiol. Aging 2003, 24, 197-211. [CrossRef]

45. Jellinger, K.A. A critical evaluation of current staging of alpha-synuclein pathology in Lewy body disorders. Biochim. Biophys. Acta 2009, 1792, 730-740. [CrossRef]

46. Braak, H.; Ghebremedhin, E.; Rüb, U.; Bratzke, H.; Del Tredici, K. Stages in the development of Parkinson's disease-related pathology. Cell Tissue Res. 2004, 318, 121-134. [CrossRef]

47. Hawkes, C.H.; Del Tredici, K.; Braak, H. Parkinson's disease: A dual-hit hypothesis. Neuropathol. Appl. Neurobiol. 2007, 33, 599-614. [CrossRef]

48. Dickson, D.W.; Fujishiro, H.; DelleDonne, A.; Menke, J.; Ahmed, Z.; Klos, K.J.; Josephs, K.A.; Frigerio, R.; Burnett, M.; Parisi, J.E.; et al. Evidence that incidental Lewy body disease is pre-symptomatic Parkinson's disease. Acta Neuropathol. 2008, 115, 437-444. [CrossRef]

49. Tsuboi, Y.; Uchikado, H.; Dickson, D.W. Neuropathology of Parkinson's disease dementia and dementia with Lewy bodies with reference to striatal pathology. Parkinsonism Relat. Disord. 2007, 13 (Suppl. 3), S221-S224. [CrossRef]

50. McKeith, I.G.; Dickson, D.W.; Lowe, J.; Emre, M.; O’Brien, J.T.; Feldman, H.; Cummings, J.; Duda, J.E.; Lippa, C.; Perry, E.K.; et al. Diagnosis and management of dementia with Lewy bodies: Third report of the DLB Consortium. Neurology 2005, 65, 1863-1872. [CrossRef]

51. Zaccai, J.; Brayne, C.; McKeith, I.; Matthews, F.; Ince, P.G. Patterns and stages of alpha-synucleinopathy: Relevance in a population-based cohort. Neurology 2008, 70, 1042-1048. [CrossRef] [PubMed]

52. Spillantini, M.G.; Crowther, R.A.; Jakes, R.; Cairns, N.J.; Lantos, P.L.; Goedert, M. Filamentous alpha-synuclein inclusions link multiple system atrophy with Parkinson's disease and dementia with Lewy bodies. Neurosci. Lett. 1998, 251, 205-208. [CrossRef]

53. Gilman, S.; Wenning, G.K.; Low, P.A.; Brooks, D.J.; Mathias, C.J.; Trojanowski, J.Q.; Wood, N.W.; Colosimo, C.; Durr, A.; Fowler, C.J.; et al. Second consensus statement on the diagnosis of multiple system atrophy. Neurology 2008, 71, 670-676. [CrossRef]

54. Kaji, S.; Maki, T.; Ishimoto, T.; Yamakado, H.; Takahashi, R. Insights into the pathogenesis of multiple system atrophy: Focus on glial cytoplasmic inclusions. Transl. Neurodegener. 2020, 9, 7. [CrossRef]

55. Cykowski, M.D.; Coon, E.A.; Powell, S.Z.; Jenkins, S.M.; Benarroch, E.E.; Low, P.A.; Schmeichel, A.M.; Parisi, J.E. Expanding the spectrum of neuronal pathology in multiple system atrophy. Brain 2015, 138, 2293-2309. [CrossRef] [PubMed]

56. Duda, J.E.; Giasson, B.I.; Gur, T.L.; Montine, T.J.; Robertson, D.; Biaggioni, I.; Hurtig, H.I.; Stern, M.B.; Gollomp, S.M.; Grossman, M.; et al. Immunohistochemical and biochemical studies demonstrate a distinct profile of alpha-synuclein permutations in multiple system atrophy. J. Neuropathol. Exp. Neurol. 2000, 59, 830-841. [CrossRef]

57. Brettschneider, J.; Irwin, D.J.; Boluda, S.; Byrne, M.D.; Fang, L.; Lee, E.B.; Robinson, J.L.; Suh, E.; Van Deerlin, V.M.; Toledo, J.B.; et al. Progression of alpha-synuclein pathology in multiple system atrophy of the cerebellar type. Neuropathol. Appl. Neurobiol. 2017, 43, 315-329. [CrossRef] 
58. Fujishiro, H.; Ahn, T.-B.; Frigerio, R.; DelleDonne, A.; Josephs, K.A.; Parisi, J.E.; Eric Ahlskog, J.; Dickson, D.W. Glial cytoplasmic inclusions in neurologically normal elderly: Prodromal multiple system atrophy? Acta Neuropathol. 2008, 116, 269-275. [CrossRef] [PubMed]

59. Koga, S.; Li, F.; Zhao, N.; Roemer, S.F.; Ferman, T.J.; Wernick, A.I.; Walton, R.L.; Faroqi, A.H.; Graff-Radford, N.R.; Cheshire, W.P.; et al. Clinicopathologic and genetic features of multiple system atrophy with Lewy body disease. Brain Pathol. 2020, 30, 766-778. [CrossRef]

60. Hague, K.; Lento, P.; Morgello, S.; Caro, S.; Kaufmann, H. The distribution of Lewy bodies in pure autonomic failure: Autopsy findings and review of the literature. Acta Neuropathol. 1997, 94, 192-196. [CrossRef]

61. Li, J.-Y.; Englund, E.; Holton, J.L.; Soulet, D.; Hagell, P.; Lees, A.J.; Lashley, T.; Quinn, N.P.; Rehncrona, S.; Björklund, A.; et al. Lewy bodies in grafted neurons in subjects with Parkinson's disease suggest host-to-graft disease propagation. Nat. Med. 2008, 14, 501-503. [CrossRef] [PubMed]

62. Kordower, J.H.; Brundin, P. Lewy body pathology in long-term fetal nigral transplants: Is Parkinson's disease transmitted from one neural system to another? Neuropsychopharmacology 2009, 34, 254. [CrossRef]

63. Uchihara, T.; Giasson, B.I. Propagation of alpha-synuclein pathology: Hypotheses, discoveries, and yet unresolved questions from experimental and human brain studies. Acta Neuropathol. 2016, 131, 49-73. [CrossRef] [PubMed]

64. Goedert, M.; Masuda-Suzukake, M.; Falcon, B. Like prions: The propagation of aggregated tau and $\alpha$-synuclein in neurodegeneration. Brain 2017, 140, 266-278. [CrossRef]

65. Stokholm, M.G.; Danielsen, E.H.; Hamilton-Dutoit, S.J.; Borghammer, P. Pathological $\alpha$-synuclein in gastrointestinal tissues from prodromal Parkinson disease patients. Ann. Neurol. 2016, 79, 940-949. [CrossRef]

66. Chiang, H.-L.; Lin, C.-H. Altered Gut Microbiome and Intestinal Pathology in Parkinson's Disease. J. Mov. Disord. 2019, 12, 67-83. [CrossRef]

67. Skjærbæk, C.; Knudsen, K.; Horsager, J.; Borghammer, P. Gastrointestinal Dysfunction in Parkinson's Disease. J. Clin. Med. 2021, 10, 493. [CrossRef] [PubMed]

68. Orimo, S.; Uchihara, T.; Nakamura, A.; Mori, F.; Kakita, A.; Wakabayashi, K.; Takahashi, H. Axonal alpha-synuclein aggregates herald centripetal degeneration of cardiac sympathetic nerve in Parkinson's disease. Brain 2008, 131, 642-650. [CrossRef]

69. Kim, J.Y.; Illigens, B.M.; McCormick, M.P.; Wang, N.; Gibbons, C.H. Alpha-Synuclein in Skin Nerve Fibers as a Biomarker for Alpha-Synucleinopathies. J. Clin. Neurol. 2019, 15, 135-142. [CrossRef]

70. Donadio, V.; Incensi, A.; Rizzo, G.; De Micco, R.; Tessitore, A.; Devigili, G.; Del Sorbo, F.; Bonvegna, S.; Infante, R.; Magnani, M.; et al. Skin Biopsy May Help to Distinguish Multiple System Atrophy-Parkinsonism from Parkinson's Disease With Orthostatic Hypotension. Mov. Disord. 2020, 35, 1649-1657. [CrossRef]

71. Brumberg, J.; Kuzkina, A.; Lapa, C.; Mammadova, S.; Buck, A.; Volkmann, J.; Sommer, C.; Isaias, I.U.; Doppler, K. Dermal and cardiac autonomic fiber involvement in Parkinson's disease and multiple system atrophy. Neurobiol. Dis. 2021, 153, 105332. [CrossRef]

72. Leclair-Visonneau, L.; Clairembault, T.; Coron, E.; Le Dily, S.; Vavasseur, F.; Dalichampt, M.; Péréon, Y.; Neunlist, M.; Derkinderen, P. REM sleep behavior disorder is related to enteric neuropathology in Parkinson disease. Neurology 2017, 89, 1612-1618. [CrossRef] [PubMed]

73. Donadio, V.; Incensi, A.; Del Sorbo, F.; Rizzo, G.; Infante, R.; Scaglione, C.; Modugno, N.; Fileccia, E.; Elia, A.E.; Cencini, F.; et al. Skin Nerve Phosphorylated $\alpha$-Synuclein Deposits in Parkinson Disease with Orthostatic Hypotension. J. Neuropathol. Exp. Neurol. 2018, 77, 942-949. [CrossRef]

74. Hirayama, M. Sweating dysfunctions in Parkinson's disease. J. Neurol. 2006, 253, vii42-vii47. [CrossRef]

75. Cheon, S.-M.; Ha, M.-S.; Park, M.J.; Kim, J.W. Nonmotor symptoms of Parkinson's disease: Prevalence and awareness of patients and families. Parkinsonism Relat. Disord. 2008, 14, 286-290. [CrossRef]

76. Palma, J.-A.; Kaufmann, H. Orthostatic Hypotension in Parkinson Disease. Clin. Geriatr. Med. 2020, 36, 53-67. [CrossRef]

77. Angot, E.; Steiner, J.A.; Hansen, C.; Li, J.-Y.; Brundin, P. Are synucleinopathies prion-like disorders? Lancet Neurol. 2010, 9 , 1128-1138. [CrossRef]

78. Jan, A.; Gonçalves, N.P.; Vaegter, C.B.; Jensen, P.H.; Ferreira, N. The Prion-Like Spreading of Alpha-Synuclein in Parkinson's Disease: Update on Models and Hypotheses. Int. J. Mol. Sci. 2021, 22, 8338. [CrossRef]

79. Ferreira, N.; Gonçalves, N.P.; Jan, A.; Jensen, N.M.; van der Laan, A.; Mohseni, S.; Vægter, C.B.; Jensen, P.H. Trans-synaptic spreading of alpha-synuclein pathology through sensory afferents leads to sensory nerve degeneration and neuropathic pain. Acta Neuropathol. Commun. 2021, 9, 31. [CrossRef]

80. Braak, H.; Rüb, U.; Gai, W.P.; Del Tredici, K. Idiopathic Parkinson's disease: Possible routes by which vulnerable neuronal types may be subject to neuroinvasion by an unknown pathogen. J. Neural Transm. 2003, 110, 517-536. [CrossRef]

81. Pan-Montojo, F.; Anichtchik, O.; Dening, Y.; Knels, L.; Pursche, S.; Jung, R.; Jackson, S.; Gille, G.; Spillantini, M.G.; Reichmann, H.; et al. Progression of Parkinson's disease pathology is reproduced by intragastric administration of rotenone in mice. PLoS ONE 2010, 5, e8762. [CrossRef] [PubMed]

82. Van Den Berge, N.; Ferreira, N.; Gram, H.; Mikkelsen, T.W.; Alstrup, A.K.O.; Casadei, N.; Tsung-Pin, P.; Riess, O.; Nyengaard, J.R.; Tamgüney, G.; et al. Evidence for bidirectional and trans-synaptic parasympathetic and sympathetic propagation of alpha-synuclein in rats. Acta Neuropathol. 2019, 138, 535-550. [CrossRef] [PubMed] 
83. Van Den Berge, N.; Ferreira, N.; Mikkelsen, T.W.; Alstrup, A.K.O.; Tamgüney, G.; Karlsson, P.; Terkelsen, A.J.; Nyengaard, J.R.; Jensen, P.H.; Borghammer, P. Ageing promotes pathological alpha-synuclein propagation and autonomic dysfunction in wild-type rats. Brain 2021, 144, 1853-1868. [CrossRef] [PubMed]

84. Kim, S.; Kwon, S.H.; Kam, T.I.; Panicker, N.; Karuppagounder, S.S.; Lee, S.; Lee, J.H.; Kim, W.R.; Kook, M.; Foss, C.A.; et al. Transneuronal Propagation of Pathologic $\alpha$-Synuclein from the Gut to the Brain Models Parkinson's Disease. Neuron 2019, 103, 627-641.e7. [CrossRef]

85. Svensson, E.; Horváth-Puhó, E.; Thomsen, R.W.; Djurhuus, J.C.; Pedersen, L.; Borghammer, P.; Sørensen, H.T. Vagotomy and subsequent risk of Parkinson's disease. Ann. Neurol. 2015, 78, 522-529. [CrossRef]

86. Liu, B.; Fang, F.; Pedersen, N.L.; Tillander, A.; Ludvigsson, J.F.; Ekbom, A.; Svenningsson, P.; Chen, H.; Wirdefeldt, K. Vagotomy and Parkinson disease: A Swedish register-based matched-cohort study. Neurology 2017, 88, 1996-2002. [CrossRef]

87. Parkkinen, L.; Pirttilä, T.; Alafuzoff, I. Applicability of current staging/categorization of alpha-synuclein pathology and their clinical relevance. Acta Neuropathol. 2008, 115, 399-407. [CrossRef]

88. Jellinger, K.A. Is Braak staging valid for all types of Parkinson's disease? J. Neural Transm. 2019, 126, 423-431. [CrossRef] [PubMed]

89. Raunio, A.; Kaivola, K.; Tuimala, J.; Kero, M.; Oinas, M.; Polvikoski, T.; Paetau, A.; Tienari, P.J.; Myllykangas, L. Lewy-related pathology exhibits two anatomically and genetically distinct progression patterns: A population-based study of Finns aged 85 . Acta Neuropathol. 2019, 138, 771-782. [CrossRef]

90. Borghammer, P.; Van Den Berge, N. Brain-First versus Gut-First Parkinson's Disease: A Hypothesis. J. Parkinsons. Dis. 2019, 9, S281-S295. [CrossRef]

91. Horsager, J.; Andersen, K.B.; Knudsen, K.; Skjærbæk, C.; Fedorova, T.D.; Okkels, N.; Schaeffer, E.; Bonkat, S.K.; Geday, J.; Otto, M.; et al. Brain-first versus body-first Parkinson's disease: A multimodal imaging case-control study. Brain 2020, 143, 3077-3088. [CrossRef]

92. Högl, B.; Stefani, A.; Videnovic, A. Idiopathic REM sleep behaviour disorder and neurodegeneration-An update. Nat. Rev. Neurol. 2018, 14, 40-55. [CrossRef]

93. McCarter, S.J.; Gehrking, T.L.; St Louis, E.K.; Suarez, M.D.; Boeve, B.F.; Silber, M.H.; Low, P.A.; Singer, W. Autonomic dysfunction and phenoconversion in idiopathic REM sleep behavior disorder. Clin. Auton. Res. Off. J. Clin. Auton. Res. Soc. 2020, 30, 207-213. [CrossRef] [PubMed]

94. Andersen, K.B.; Hansen, A.K.; Sommerauer, M.; Fedorova, T.D.; Knudsen, K.; Vang, K.; Van Den Berge, N.; Kinnerup, M.; Nahimi, A.; Pavese, N.; et al. Altered sensorimotor cortex noradrenergic function in idiopathic REM sleep behaviour disorder-A PET study. Parkinsonism Relat. Disord. 2020, 75, 63-69. [CrossRef] [PubMed]

95. Knudsen, K.; Fedorova, T.D.; Horsager, J.; Andersen, K.B.; Skjærbæk, C.; Berg, D.; Schaeffer, E.; Brooks, D.J.; Pavese, N.; Van Den Berge, N.; et al. Asymmetric Dopaminergic Dysfunction in Brain-First versus Body-First Parkinson's Disease Subtypes. J. Parkinsons. Dis. 2021, 11, 1677-1687. [CrossRef]

96. Van Den Berge, N.; Ulusoy, A. Animal models of brain-first and body-first Parkinson's disease. Neurobiol. Dis. 2021, 163, 105599. [CrossRef]

97. Fleming, S.M.; Davis, A.; Simons, E. Targeting alpha-synuclein via the immune system in Parkinson's disease: Current vaccine therapies. Neuropharmacology 2022, 202, 108870. [CrossRef]

98. Takahashi, M.; Suzuki, M.; Fukuoka, M.; Fujikake, N.; Watanabe, S.; Murata, M.; Wada, K.; Nagai, Y.; Hohjoh, H. Normalization of Overexpressed $\alpha$-Synuclein Causing Parkinson's Disease by a Moderate Gene Silencing with RNA Interference. Mol. Ther. Nucleic Acids 2015, 4, e241. [CrossRef]

99. Kim, Y.-C.; Miller, A.; Lins, L.C.R.F.; Han, S.-W.; Keiser, M.S.; Boudreau, R.L.; Davidson, B.L.; Narayanan, N.S. RNA Interference of Human $\alpha$-Synuclein in Mouse. Front. Neurol. 2017, 8, 13. [CrossRef] [PubMed]

100. Xilouri, M.; Brekk, O.R.; Stefanis, L. Autophagy and Alpha-Synuclein: Relevance to Parkinson's Disease and Related Synucleopathies. Mov. Disord. 2016, 31, 178-192. [CrossRef]

101. Pena-Diaz, S.; Pujols, J.; Ventura, S. Small molecules to prevent the neurodegeneration caused by $\alpha$-synuclein aggregation. Neural Regen. Res. 2020, 15, 2260-2261. [CrossRef]

102. Meissner, W.G.; Traon, A.P.-L.; Foubert-Samier, A.; Galabova, G.; Galitzky, M.; Kutzelnigg, A.; Laurens, B.; Lührs, P.; Medori, R.; Péran, P.; et al. A Phase 1 Randomized Trial of Specific Active $\alpha$-Synuclein Immunotherapies PD01A and PD03A in Multiple System Atrophy. Mov. Disord. 2020, 35, 1957-1965. [CrossRef]

103. Nimmo, J.T.; Smith, H.; Wang, C.Y.; Teeling, J.L.; Nicoll, J.A.R.; Verma, A.; Dodart, J.-C.; Liu, Z.; Lin, F.; Carare, R.O. Immunisation with UB-312 in the Thy1SNCA mouse prevents motor performance deficits and oligomeric $\alpha$-synuclein accumulation in the brain and gut. Acta Neuropathol. 2021, 143, 55-73. [CrossRef]

104. Sulzer, D.; Alcalay, R.N.; Garretti, F.; Cote, L.; Kanter, E.; Agin-Liebes, J.; Liong, C.; McMurtrey, C.; Hildebrand, W.H.; Mao, X.; et al. T cells from patients with Parkinson's disease recognize $\alpha$-synuclein peptides. Nature 2017, 546, 656-661. [CrossRef]

105. Lindestam Arlehamn, C.S.; Dhanwani, R.; Pham, J.; Kuan, R.; Frazier, A.; Rezende Dutra, J.; Phillips, E.; Mallal, S.; Roederer, M.; Marder, K.S.; et al. $\alpha$-Synuclein-specific T cell reactivity is associated with preclinical and early Parkinson's disease. Nat. Commun. 2020, 11, 1875. [CrossRef] 
106. Masliah, E.; Rockenstein, E.; Mante, M.; Crews, L.; Spencer, B.; Adame, A.; Patrick, C.; Trejo, M.; Ubhi, K.; Rohn, T.T.; et al. Passive immunization reduces behavioral and neuropathological deficits in an alpha-synuclein transgenic model of lewy body disease. PLoS ONE 2011, 6, e19338. [CrossRef]

107. Bae, E.-J.; Lee, H.-J.; Rockenstein, E.; Ho, D.-H.; Park, E.-B.; Yang, N.-Y.; Desplats, P.; Masliah, E.; Lee, S.-J. Antibody-aided clearance of extracellular $\alpha$-synuclein prevents cell-to-cell aggregate transmission. J. Neurosci. 2012, 32, 13454-13469. [CrossRef]

108. Tran, H.T.; Chung, C.H.-Y.; Iba, M.; Zhang, B.; Trojanowski, J.Q.; Luk, K.C.; Lee, V.M.Y. A-synuclein immunotherapy blocks uptake and templated propagation of misfolded $\alpha$-synuclein and neurodegeneration. Cell Rep. 2014, 7, 2054-2065. [CrossRef]

109. Lindström, V.; Fagerqvist, T.; Nordström, E.; Eriksson, F.; Lord, A.; Tucker, S.; Andersson, J.; Johannesson, M.; Schell, H.; Kahle, P.J.; et al. Immunotherapy targeting $\alpha$-synuclein protofibrils reduced pathology in (Thy-1)-h[A30P] $\alpha$-synuclein mice. Neurobiol. Dis. 2014, 69, 134-143. [CrossRef]

110. Shahaduzzaman, M.; Nash, K.; Hudson, C.; Sharif, M.; Grimmig, B.; Lin, X.; Bai, G.; Liu, H.; Ugen, K.E.; Cao, C.; et al. Anti-human $\alpha$-synuclein $\mathrm{N}$-terminal peptide antibody protects against dopaminergic cell death and ameliorates behavioral deficits in an AAV- $\alpha$-synuclein rat model of Parkinson's disease. PLoS ONE 2015, 10, e0116841. [CrossRef]

111. El-Agnaf, O.; Overk, C.; Rockenstein, E.; Mante, M.; Florio, J.; Adame, A.; Vaikath, N.; Majbour, N.; Lee, S.-J.; Kim, C.; et al. Differential effects of immunotherapy with antibodies targeting $\alpha$-synuclein oligomers and fibrils in a transgenic model of synucleinopathy. Neurobiol. Dis. 2017, 104, 85-96. [CrossRef]

112. Spencer, B.; Valera, E.; Rockenstein, E.; Overk, C.; Mante, M.; Adame, A.; Zago, W.; Seubert, P.; Barbour, R.; Schenk, D.; et al. Anti- $\alpha$-synuclein immunotherapy reduces $\alpha$-synuclein propagation in the axon and degeneration in a combined viral vector and transgenic model of synucleinopathy. Acta Neuropathol. Commun. 2017, 5, 7. [CrossRef]

113. Kallab, M.; Herrera-Vaquero, M.; Johannesson, M.; Eriksson, F.; Sigvardson, J.; Poewe, W.; Wenning, G.K.; Nordström, E.; Stefanova, N. Region-Specific Effects of Immunotherapy with Antibodies Targeting $\alpha$-synuclein in a Transgenic Model of Synucleinopathy. Front. Neurosci. 2018, 12, 452. [CrossRef]

114. Schofield, D.J.; Irving, L.; Calo, L.; Bogstedt, A.; Rees, G.; Nuccitelli, A.; Narwal, R.; Petrone, M.; Roberts, J.; Brown, L.; et al Preclinical development of a high affinity $\alpha$-synuclein antibody, MEDI1341, that can enter the brain, sequester extracellular $\alpha$-synuclein and attenuate $\alpha$-synuclein spreading in vivo. Neurobiol. Dis. 2019, 132, 104582. [CrossRef]

115. Huang, Y.-R.; Xie, X.-X.; Ji, M.; Yu, X.-L.; Zhu, J.; Zhang, L.-X.; Liu, X.-G.; Wei, C.; Li, G.; Liu, R.-T. Naturally occurring autoantibodies against $\alpha$-synuclein rescues memory and motor deficits and attenuates $\alpha$-synuclein pathology in mouse model of Parkinson's disease. Neurobiol. Dis. 2019, 124, 202-217. [CrossRef]

116. Henderson, M.X.; Covell, D.J.; Chung, C.H.-Y.; Pitkin, R.M.; Sandler, R.M.; Decker, S.C.; Riddle, D.M.; Zhang, B.; Gathagan, R.J.; James, M.J.; et al. Characterization of novel conformation-selective $\alpha$-synuclein antibodies as potential immunotherapeutic agents for Parkinson's disease. Neurobiol. Dis. 2020, 136, 104712. [CrossRef]

117. Weihofen, A.; Liu, Y.; Arndt, J.W.; Huy, C.; Quan, C.; Smith, B.A.; Baeriswyl, J.-L.; Cavegn, N.; Senn, L.; Su, L.; et al. Development of an aggregate-selective, human-derived $\alpha$-synuclein antibody BIIB054 that ameliorates disease phenotypes in Parkinson's disease models. Neurobiol. Dis. 2019, 124, 276-288. [CrossRef]

118. Chen, Y.-H.; Wu, K.-J.; Hsieh, W.; Harvey, B.K.; Hoffer, B.J.; Wang, Y.; Yu, S.-J. Administration of AAV-Alpha Synuclein NAC Antibody Improves Locomotor Behavior in Rats Overexpressing Alpha Synuclein. Genes 2021, 12, 948. [CrossRef]

119. Nordström, E.; Eriksson, F.; Sigvardson, J.; Johannesson, M.; Kasrayan, A.; Jones-Kostalla, M.; Appelkvist, P.; Söderberg, L.; Nygren, P.; Blom, M.; et al. ABBV-0805, a novel antibody selective for soluble aggregated $\alpha$-synuclein, prolongs lifespan and prevents buildup of $\alpha$-synuclein pathology in mouse models of Parkinson's disease. Neurobiol. Dis. 2021, 161, 105543. [CrossRef]

120. Masliah, E.; Rockenstein, E.; Adame, A.; Alford, M.; Crews, L.; Hashimoto, M.; Seubert, P.; Lee, M.; Goldstein, J.; Chilcote, T.; et al. Effects of alpha-synuclein immunization in a mouse model of Parkinson's disease. Neuron 2005, 46, 857-868. [CrossRef]

121. Gorbatyuk, O.S.; Li, S.; Nash, K.; Gorbatyuk, M.; Lewin, A.S.; Sullivan, L.F.; Mandel, R.J.; Chen, W.; Meyers, C.; Manfredsson, F.P.; et al. In vivo RNAi-mediated alpha-synuclein silencing induces nigrostriatal degeneration. Mol. Ther. 2010, 18, $1450-1457$. [CrossRef]

122. Kahle, P.J.; Neumann, M.; Ozmen, L.; Muller, V.; Jacobsen, H.; Schindzielorz, A.; Okochi, M.; Leimer, U.; van Der Putten, H.; Probst, A.; et al. Subcellular localization of wild-type and Parkinson's disease-associated mutant alpha -synuclein in human and transgenic mouse brain. J. Neurosci. 2000, 20, 6365-6373. [CrossRef]

123. Kuo, Y.-M.; Li, Z.; Jiao, Y.; Gaborit, N.; Pani, A.K.; Orrison, B.M.; Bruneau, B.G.; Giasson, B.I.; Smeyne, R.J.; Gershon, M.D.; et al. Extensive enteric nervous system abnormalities in mice transgenic for artificial chromosomes containing Parkinson diseaseassociated alpha-synuclein gene mutations precede central nervous system changes. Hum. Mol. Genet. 2010, 19, 1633-1650. [CrossRef]

124. Ghosh, S.S.; Wang, J.; Yannie, P.J.; Ghosh, S. Intestinal Barrier Dysfunction, LPS Translocation, and Disease Development. J. Endocr. Soc. 2020, 4, bvz039. [CrossRef] [PubMed]

125. van IJzendoorn, S.C.D.; Derkinderen, P. The Intestinal Barrier in Parkinson's Disease: Current State of Knowledge. J. Parkinsons. Dis. 2019, 9, S323-S329. [CrossRef]

126. Boertien, J.M.; Pereira, P.A.B.; Aho, V.T.E.; Scheperjans, F. Increasing Comparability and Utility of Gut Microbiome Studies in Parkinson's Disease: A Systematic Review. J. Parkinsons. Dis. 2019, 9, S297-S312. [CrossRef]

127. Brudek, T. Inflammatory Bowel Diseases and Parkinson's Disease. J. Parkinsons. Dis. 2019, 9, S331-S344. [CrossRef] 
128. Lee, H.-S.; Lobbestael, E.; Vermeire, S.; Sabino, J.; Cleynen, I. Inflammatory bowel disease and Parkinson's disease: Common pathophysiological links. Gut 2021, 70, 408-417. [CrossRef] [PubMed]

129. Kalia, L.V.; Lang, A.E. Parkinson's disease. Lancet 2015, 386, 896-912. [CrossRef]

130. Knudsen, K.; Haase, A.-M.; Fedorova, T.D.; Bekker, A.C.; Østergaard, K.; Krogh, K.; Borghammer, P. Gastrointestinal Transit Time in Parkinson's Disease Using a Magnetic Tracking System. J. Parkinsons. Dis. 2017, 7, 471-479. [CrossRef] 